\title{
Characterization of AGO-binding silencing suppressors and creating the first artificial RNA silencing suppressor
}

\author{
Ph.D. Thesis
}

\section{Edit Zsuzsanna Szabó}

Supervisor: Lóránt Lakatos Ph.D.

Department of Dermatology and Allergology,

University of Szeged

Szeged, Hungary

2015 


\section{Contents}

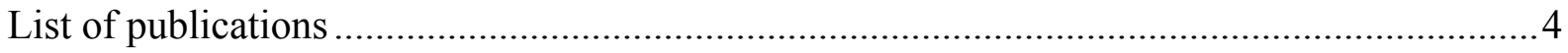

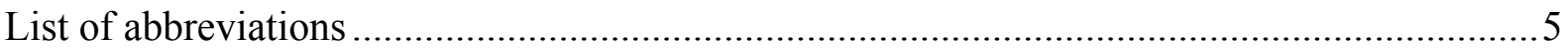

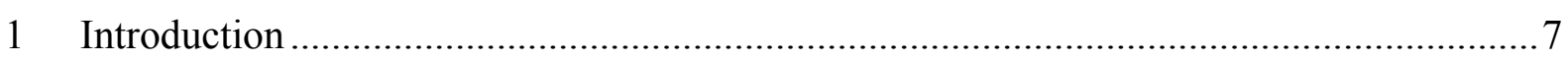

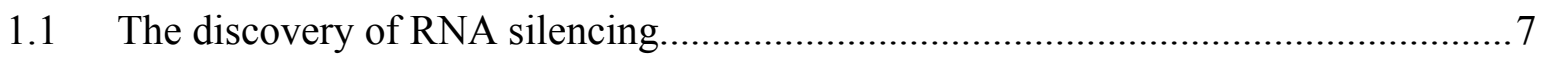

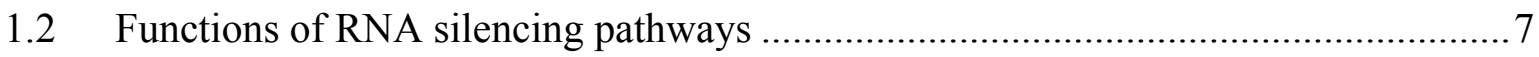

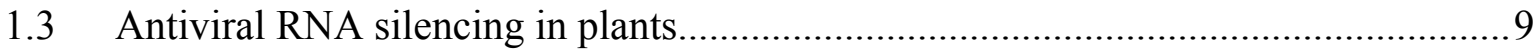

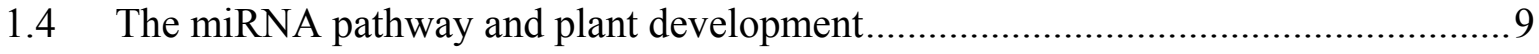

1.5 Regulation of the ta-si-RNA pathway by miRNAs .......................................... 10

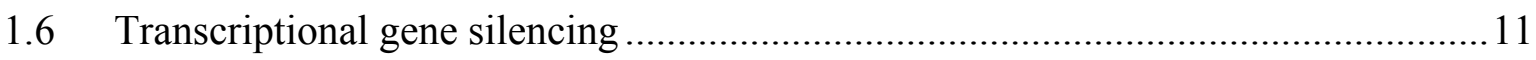

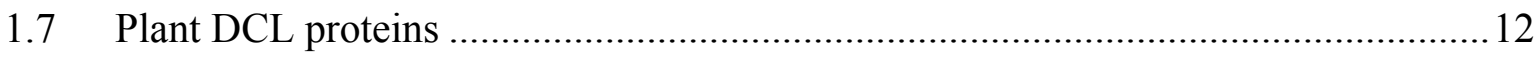

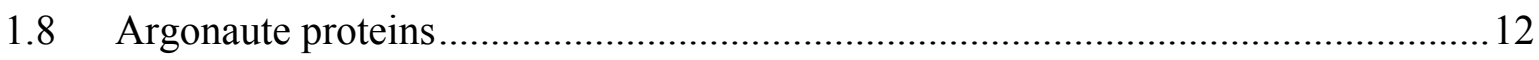

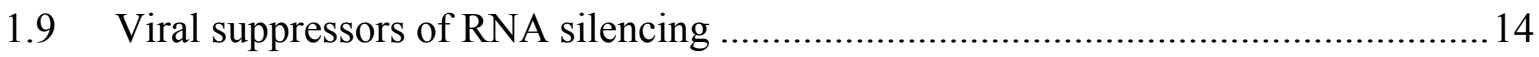

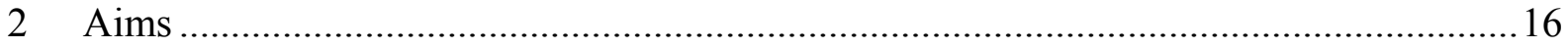

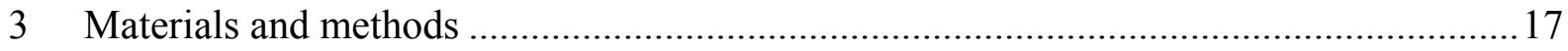

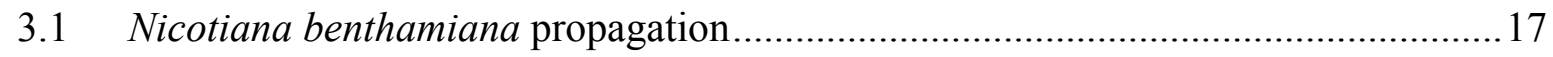

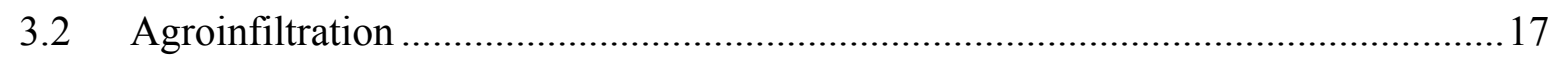

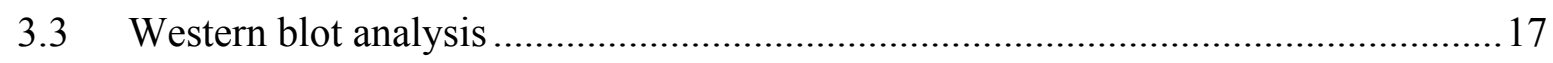

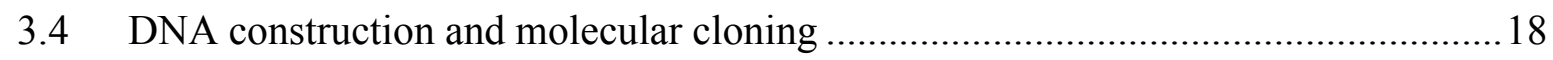

3.5 Preparation of radioactively labeled DNA probe.................................................. 19

3.6 Preparation of radioactively labeled RNA probe.....................................................19

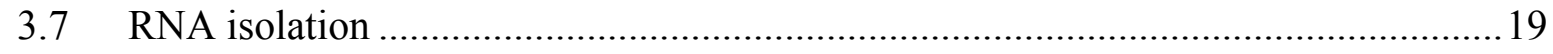

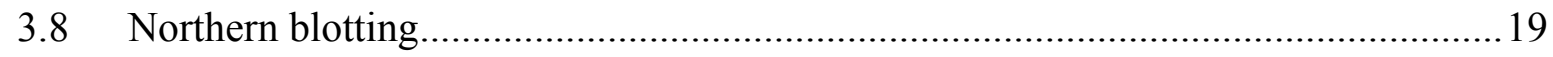

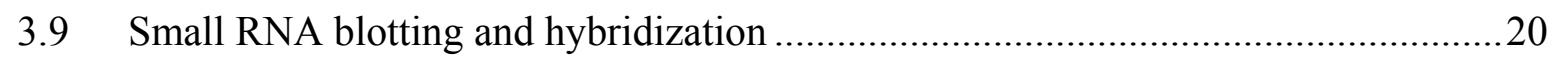

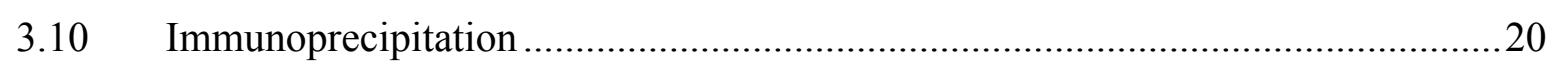

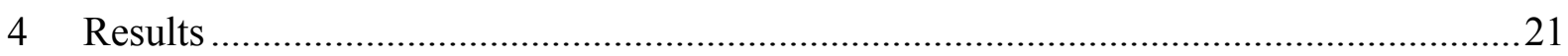

4.1 Characterization of the Argonaute binding 16K protein of the Tobacco rattle virus 21

4.2 Narrowing the silencing suppressor domain of Sweet potato mild mottle virus $\mathrm{P} 1$

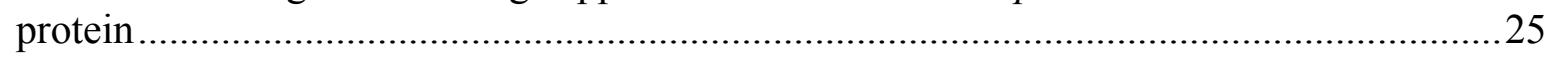

4.3 Appearance of C-terminally truncated SPMMV P1 proteins in planta .....................25

4.4 P1 protein of the Sweet potato feathery mottle virus is the closest homologue of

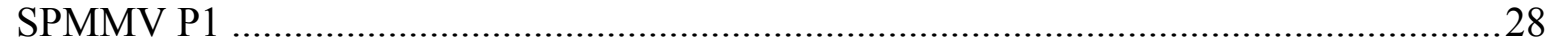

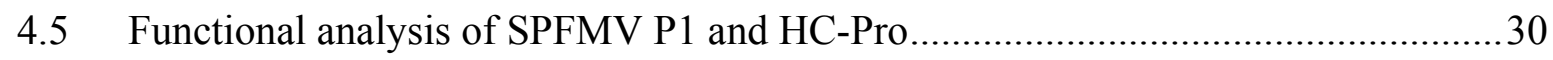

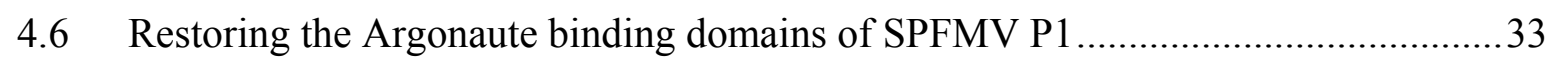




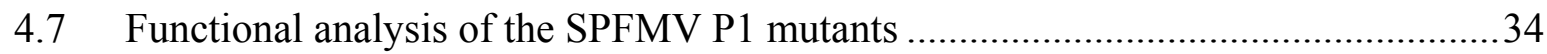

4.8 SPFMV P1 gain of function mutant is an AGO binging protein.................................

4.9 Mechanistic studies of the SPFMV P1 gain of function mutant...............................37

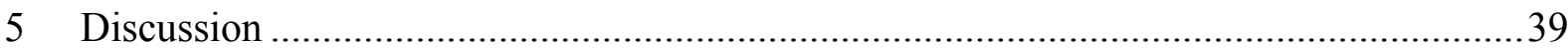

5.1 Understanding the link between physiology and the working mechanism of the $16 \mathrm{~K}$

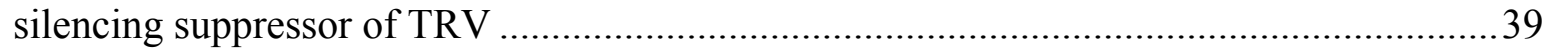

5.2 The minimal silencing suppressor domain of the SPMMV P1 ...............................41

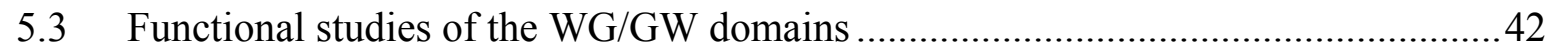

5.4 Possible working mechanism for SPFMV P1 gain of function mutant ....................44

5.5 Sequence specific versus sequence non-specific silencing suppressors ...................44

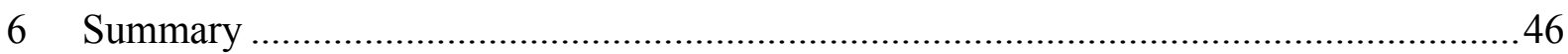

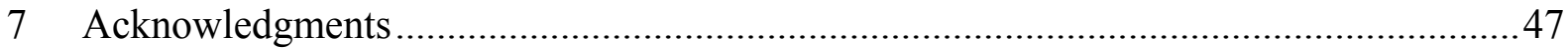

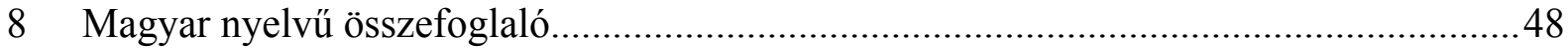

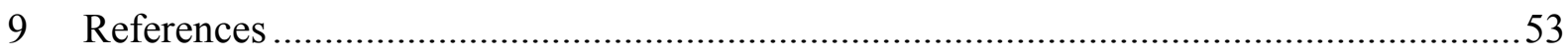




\section{List of publications}

\section{Publications directly related to subject of the dissertation}

1. Szabó EZ, Manczinger M, Göblös A, Kemény L, Lakatos L. (2012): Switching on RNA silencing suppressor activity by restoring argonaute binding to a viral protein. J Virol. (15):8324-7.

2. Edit Zsuzsanna Szabó, Lajos Kemény, Lóránt Lakatos (2014): Deletion series in the P1 protein of the Sweet potato mild mottle virus identifies the shortest fully functional RNA silencing suppressor domain. Acta Biol Szeged, $58(2): 163-166$ 


\section{List of abbreviations}

\begin{tabular}{|c|c|}
\hline A. thaliana & Arabidopsis thaliana \\
\hline $\mathrm{AGO}$ & Argonaute protein \\
\hline $\mathrm{bp}$ & Basispair \\
\hline C. elegans & Caenorhabditis elegans \\
\hline cDNA & complementary dezoxyribonucleic acid \\
\hline CymRSV & Cymbidium ringspot tombusvirus \\
\hline DCL & Dicer-like \\
\hline dpi & days post infiltration \\
\hline DRM & domain rearranged methyltransferases \\
\hline dsRNA & duple stranded RNA \\
\hline DTT & Dithiothreitol \\
\hline EDTA & Ethylenediaminetetraacetic acid \\
\hline GFP & Green fluorescent protein \\
\hline Gly (G) & Glycine \\
\hline HA-tag & Human influenza hemagglutinin \\
\hline HDA & Histone deacetylase \\
\hline His $(\mathrm{H})$ & Histidine \\
\hline LB medium & Lysogeny broth medium \\
\hline MES & 2-(N-morpholino)ethanesulfonic acid \\
\hline MET & methyltransferase \\
\hline miRNA (MiR) & micro RNA \\
\hline MOPS & 3-(N-morpholino)propanesulfonic acid \\
\hline N. benthamiana & Nicotina benthamiana \\
\hline nat-siRNA & cis-antisense siRNA \\
\hline $\mathrm{Nt}$ & Nucleotide \\
\hline OD & Optical Density \\
\hline ORF & open reading frames \\
\hline Pol & RNA polymerase \\
\hline
\end{tabular}




\begin{tabular}{|c|c|}
\hline pre-miRNA & precursor-miRNA \\
\hline pri-miRNA & primary-miRNA \\
\hline PVDF & polyvinylidene difluoride \\
\hline ra-siRNA & repeat associated siRNA \\
\hline $\mathrm{RdDM}$ & RNA-directed DNA methylation \\
\hline RDR & RNA dependent RNA polymerase \\
\hline RISC & RNA induced silencing complex \\
\hline RNA & Ribonucleic acid \\
\hline RNAi & RNA interference \\
\hline RNAP & RNA polymerase \\
\hline SDS & sudium dodecyl sulfate \\
\hline SGS & Suppressor of gene silencing \\
\hline SGS3 & Supressor of gene silencing 3 \\
\hline siRNA & small interfering RNA \\
\hline SPFMV & Sweet potato feathery mottle virus \\
\hline SPMMV & Sweet potato mild mottle virus \\
\hline SPT5 & Supressor of Ty insertion 5 \\
\hline SPVC & Sweet potato virus $C$ \\
\hline SSC & saline-sodium citrate \\
\hline ssRNA & single stranded RNA \\
\hline ta-siRNA & trans-siRNA \\
\hline TBE & Tris/Borate/EDTA buffer \\
\hline TEV HcPro & helper-component protease of Tobacco etch virus \\
\hline TGS & transcriptional gene silencing \\
\hline TRIS & 2-Amino-2-hydroxymethyl-propane-1,3-diol \\
\hline $\operatorname{Trp}(\mathrm{W})$ & Tryptophane \\
\hline TRV & Tobacco rattle virus \\
\hline Tyr $(Y)$ & Tyrosine \\
\hline
\end{tabular}




\section{Introduction}

\subsection{The discovery of RNA silencing}

RNA silencing is an evolutionary conserved mechanism in many, if not all, eukaryotes to target and degrade aberrant endogenous or exogenous RNA molecules [1] [2] [3]. RNA silencing phenomena were first described in plants, where introduction of extra copies of the flower pigmentation gene chalcone synthase was hoped to provide more pigment in the flower, but resulted in suppression of the transgene and the endogenous RNA [4] [5]. Moreover, transgenic plants expressing untranslatable parts of plant viruses proved to be highly resistant to the homologous virus, but not to unrelated viruses [6]. Interestingly, even non-transgenic plants that recovered from a second viral infection showed resistance against an unrelated virus, which carried a sequence insert from the first inoculated virus [7]. These observations were described as 'co-suppression', 'post-transcriptional gene silencing' or 'virus- induced gene silencing'. In Neurospora crassa where introduction of homologous RNA sequences caused sequence-specific RNA degradation or 'quelling' of the endogenous gene [8]. A breakthrough in the animal field came with the observation that injection of dsRNA in C. elegans resulted in degradation of endogenous mRNA and this was introduced as 'RNA interference' (RNAi) [9]. A breakthrough was achieved when it was found that shorter forms of the sense and antisense strand derived from longer dsRNA and the subsequent discovery of $\sim 25$ nucleotides (nt) small interfering (si)RNA molecules now considered as a hallmark of RNA silencing [10].

Identification of endogenous small RNA molecules, named as micro (mi)RNAs, involved in development had also big impact on RNA silencing research. The miRNAs, lin-4 and let-7 miRNAs, were shown to be required for proper larval development in C. elegans [11].

\subsection{Functions of RNA silencing pathways}

The biochemistry of RNA silencing has been best studied using Drosophila embryo extracts and can be regarded as a two-step reaction; initiation and effector phases. The initiation step is characterized by the endonucleolytic cleavage of longer dsRNA molecules 
into siRNA or miRNA species. These small RNAs are 21-26 bp in size and contain 2 nt 3'overhangs and 5'- phosphorylated termini, which are characteristic for their production by RNase-III-type enzymes from the Drosha/Dicer protein family [12] [13]. The siRNA and miRNA molecules differ in their origin and structure. While siRNAs originate from perfect complementary dsRNA duplexes, miRNAs contain mismatches, bulges or G:U wobble base pairs. MiRNA molecules are host-encoded and derive from long non-coding single stranded (ss) RNAs [14].

In the effector step of the RNA silencing pathway, one strand of the siRNA or miRNA duplex is loaded onto a ribonucleoprotein complex, the RNA induced silencing complex (RISC) for sequence specific identification of target RNAs [3]. Enzymatic activity of members of the Argonaute (AGO) protein family enables the preassembled RISC to slice complementary mRNAs or arrest their translation [13]. Molecular and genetic analysis in plants and animals have revealed many RNA silencing pathways in which different small RNAs and RNA silencing proteins are key players. A schematic overview of these small RNA silencing pathways is shown in Figure 1.

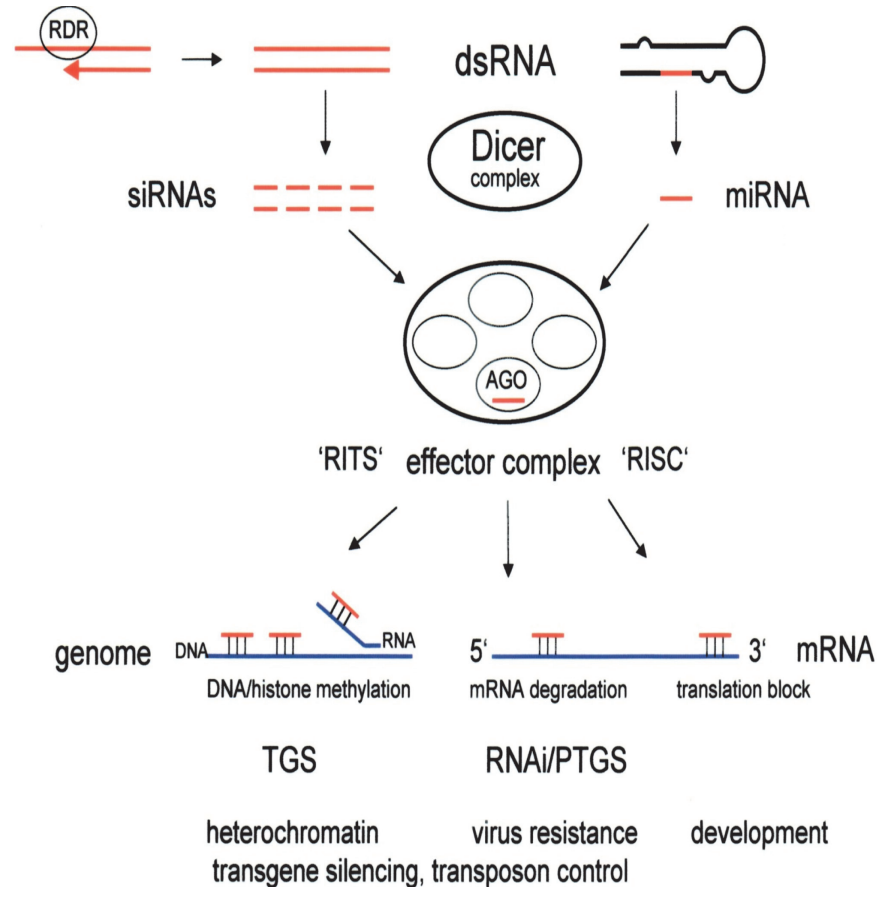

Figure 1. Summary of the RNA silencing pathways SsRNA doublestranded by RDR, nature dsRNA, or premiRNA could serve as trigger RNA. Trigger RNAs are processed by DICERs into small RNAs. Small RNAs are loaded into effector complexes (RISC) with different functions. In the nucleus, RISCs are involved in transcriptional silencing and heterochromatin formation. RISCs in the cytoplasm could be involved in miRNA silencing and antiviral silencing in plant. 


\subsection{Antiviral RNA silencing in plants}

As it acts as antiviral mechanism, the siRNA-mediated pathway is the most relevant RNA silencing pathway for plant virology. Antiviral silencing acts in the cytoplasm and is initiated predominantly by highly-structured viral ssRNAs, dsRNA replication intermediates of plant viruses, cytoplasmically replicating viruses or dsRNA produced by plant RNA dependent RNA polymerase (RDR) action (RDR1 or RDR6) [15] [16]. These dsRNA molecules are recognized by one of the four plant dicer enzymes; Dicer-like (DCL) 4 and subsequently processed into virus-specific siRNAs [17] [18]. In plants, RDR6 is also involved in a process called transitivity, which can occur in both $5^{\prime}$ and $3^{\prime}$ direction of the cut initiated by the primary siRNA [19]. This possibly reflects RDR6 primer-dependent 5' spreading and primer-independent 3' spreading, respectively. The newly synthesized dsRNAs are subsequently recognised by DCL4 to generate secondary siRNAs of exclusively $21 \mathrm{nt}$ in size [19], thereby amplifying silencing. Interestingly, a second class of antiviral siRNAs (24-26 nt) can be generated specifically in plants, which seem to be involved in long-distance systemic silencing and are proposed to travel to different plant organs in advance of the invading virus [20] [21].

\subsection{The miRNA pathway and plant development}

In plants and animals, miRNAs are produced from endogenous partially folded transcripts. MiRNAs act in trans by targeting cellular transcripts with small stretches of homology by mostly inhibiting their translation. However, target degradation is more common in plants, while translational inhibition is a main feature of animals [14]. Primary (pri)-miRNAs are synthetized by RNA polymerase II (Pol II) from MIR genes in plants [22] In animals, the pre-miRNA is recognized by the Drosha protein complex and cleaved into precursor (pre-)miRNAs. These are subsequently exported from the nucleus into the cytoplasm by Exportin-5 and processed by Dicer into mature miRNA/miRNA* duplexes of $21 \mathrm{nt}$ in size [23]. Because of the limited complementarity between the 5' end of the miRNA (the seed region) and its target, animal miRNAs guide translational repression of their targets [14]. In plants, the pri-miRNAs are recognized and cleaved by DCL1 that interacts with HYL1 to generate proper length miRNA/miRNA* duplexes in the nucleus [24]. 
MiRNA/miRNA* duplexes are methylated by HEN1, which also methylates siRNAs. Methylation of these small RNA molecules most likely protects them from degradation and polyuridylation processes [25]. The miRNA/miRNA* duplexes are subsequently exported out of the nucleus by HASTY, an ortholog of Exportin-5 [26] and the miRNA strand is incorporated into a RISC-like complex and the miRNA* strand degraded. In contrast to miRNA-mediated RNA silencing in animals, which mainly acts by translational inhibition, plant miRNAs most often guide AGO1-catalyzed mRNA cleavage [27]. Interestingly, miR162 and miR168 guide specific cleavage of DCL1 and AGO1 mRNAs, respectively [28] [29]. Since DCL1 is indispensable for miRNA production and AGO1 utilizes these mature miRNAs for mRNA cleavage, this mechanism functions as a negative feedback mechanism and is probably essential for the maintenance of steady-state levels of miRNAs [28].

\subsection{Regulation of the ta-si-RNA pathway by miRNAs}

In plants, two additional classes of endogenous small RNAs other than miRNAs are found to be active in gene regulation; transacting and natural siRNAs. The first class most likely is unique for plants and consists of trans-acting siRNAs (ta-siRNAs) that derive from $T A S$ genes and are processed by DCL4 [30] [31]. TAS primary transcripts are initially cleaved by a specific miRNA molecule and one of the two liberated strands is transformed into dsRNA by the action of RDR6 and SGS3 (Suppressor of gene silencing 3). These newly RDR6-synthesized TAS dsRNA molecules are processed by DCL4 in a phased fashion into 21 nt ta-siRNAs which regulate gene expression by guiding cleavage of their target RNA [30]. The second class of endogenous siRNAs derives from pairs of natural cis- antisense transcripts (nat-siRNAs). One RNA strand is constitutively expressed while the other strand is likely expressed under inducible conditions [32] [33]. From the complementary region of the two single RNA strands 24 nt nat-siRNAs are generated by DCL2 action. These 24 nt natsiRNAs direct the cleavage of the constitutive transcript and guide the sequential generation of $21 \mathrm{nt}$ nat-siRNAs by DCL1. 4-20\% of the genes in studied eukaryotes show a cis-antisense overlapping organization and therefore nat-siRNAs could be a major mechanism for gene expression regulation [32]. 


\subsection{Transcriptional gene silencing}

SiRNAs also play a key role in transcriptional gene silencing (TGS) that is active in the nucleus. TGS was discovered when tobacco plants were infected with Potato spindle tuber viroid. During this viroid infection, plant genome-integrated cDNA copies of the viroid became methylated de novo [34]. This suggests that replication of viroids initiates methylation of the homologous DNA copies. This phenomenon was termed as RNA-directed DNA methylation (RdDM). A role for RNA silencing in RdDM was indicated when methylation of promoters and subsequent TGS was observed when dsRNAs containing target promoter sequences were expressed in plants. RdDM is limited to the region of homology between DNA and RNA and results in the methylation of cytosines by 'domain rearranged methyltransferases' [35] (DRM1 and DRM2) and DNA methyltransferase MET1 [36]. More recently, it has been observed that the siRNA-dependent de novo methylation of DNA in plants is maintained by histone modifications [37]. The RNA-independent maintenance of CG dinucleotide methylation requires the actions of MET1 and histone deacetylase HDA6 [38]. The maintenance of the second type of nucleotide methylation, $\mathrm{CNG}$, and histone $\mathrm{H} 3$ lysine 9 (H3K9) is depending on the action of DNA methyltransferase CMT3 and the H3K9 methyltransferase SUVH4 [39]. Furthermore, the role of RNA silencing components (AGO4 and RDR2) in maintenance of $\mathrm{CNG}$ and $\mathrm{H} 3 \mathrm{~K} 9$ methylation was demonstrated. The accumulation of $24 \mathrm{nt}$ repeat associated siRNAs (ra-siRNA) from transposons and centromeric repeats is dependent on DCL3 and RDR2 action [40] and probably serves to protect the genome against damage caused by transposons [37].

Recently, other players have been identified having a keyrole in RdDM. They were identified as the $A$. thaliana RNA Pol IV and V subunits. These proteins have reiterated WG/GW motifs at their C-terminal end and have AGO4 binding activity [41]. RNA polymerase IV and V mediate RNA-directed DNA methylation and transcriptional silencing of retrotransposons and heterochromatic repeats in A. thaliana [42]. Moreover, nuclear RNA polymerase V (Pol V) is an RNA silencing enzyme recently shown to generate noncoding transcripts at loci silenced by 24-nt siRNAs. AGO4 physically interacts with these Pol V transcripts and is thereby recruited to the corresponding chromatin [43]. Interestingly, Arabidopsis Pol IV and Pol V are composed of subunits that are paralogous or identical to the 12 subunits of Pol II. Four subunits of Pol IV are distinct from their Pol II paralogs, six 
subunits of Pol V are distinct from their Pol II paralogs, and four subunits differ between Pol IV and Pol V. Importantly, the subunit differences occur in key positions relative to the template entry and RNA exit paths. Thus, Pol IV and Pol V are Pol II-like enzymes that evolved specialized roles in the production of noncoding transcripts [44].

\subsection{Plant DCL proteins}

The four DCL proteins being present in Arabidopsis generate different size classes of siRNAs from longer dsRNA molecules. DCL1 and DCL4 synthesize $21 \mathrm{nt}$ miRNAs [14] and viral siRNAs, respectively, whereas DCL2 and DCL3 serve for the processing of various long dsRNAs into 22 and 24 nt long RNAs, respectively [45]. From plant viral infection studies and individual mutations of the four DCL proteins, redundancy in DCL function has been observed [17]. DCL2 can rescue antiviral silencing against positive $(+)$ ss RNA viruses in the presence of dysfunctional DCL4 by producing $22 \mathrm{nt}$ long viral specific siRNAs. DCL3, involved in chromatin modifications, is also able to generate $24 \mathrm{nt}$ viral specific siRNA molecules in Tobacco rattle virus (TRV) and Cucumber mosaic virus infections, although these are not functional in targeting homologous viral sequences [2].

In contrast to their disability to target $(+)$ ss RNA viruses, DCL3 and DCL4 are involved in targeting plant DNA viruses. Additionally, DCL1 function is stimulated the accumulation of viral siRNA, whereas there are no indications for the contribution to antiviral RNA silencing for DCL1 in (+) ssRNA viral infections [2]. Again the activity of DCL2 in antiviral RNA silencing was eminent when DCL4 was dysfunctional in DNA virus infections [46]. The nature and origin of the DCL-generated small RNAs specify the involvement of these molecules in the various RNA silencing pathways. To date it is not clear what determines the affinity for various dsRNA molecules by DCL proteins. However, it can be envisaged that the subcellular localisation of dsRNA and DCL proteins and/or the involvement of specific dsRNA binding proteins guide the affinity for dsRNAs by DCL proteins [2].

\subsection{Argonaute proteins}

Argonaute proteins play key roles in diverse RNA silencing pathways. Like Dicer, Argonaute proteins contain a PAZ domain and a unique PIWI domain. The PAZ domain 
consists of approximately 130 amino acids and is composed of two subdomains separated by a cleft. The PAZ domain preferentially binds RNA in a sequence- independent manner and recognises the 3' of ss siRNAs. Since PAZ shows a low affinity for RNA, this suggests that other proteins of the RISC complex or other Argonaute domains may contribute to RNA binding. Besides the PAZ and PIWI domains an N-terminal and middle domain are present in Argonaute proteins.

Structural analysis of the full length Argonaute from the hyperthermophilic Archaea Pyrococcus furiosus and human showed that the PIWI domain at the C-terminus of Argonaute resembles an RNase $\mathrm{H}$ fold [47] [48]. In the catalytic domain of the Argonaute protein is a 'DDH' motif, which shows high similarity to the 'DDE' motif of the catalytic core of RNase H. Mutations in this conserved motif of human AGO2 were shown to inhibit hAGO2 slicer activity [49]. Structural predictions have shown that a large positively charged groove is formed between the PAZ domain and the folded base while a smaller groove between the $\mathrm{N}$ terminal and PIWI domains is present. During slicing the 3' end of the ss siRNA is bound by the PAZ domain and the siRNA-target interacts with the positively charged groove. The 5' region of the target is positioned between the PAZ and N-terminal domain in such a way that the catalytic core of the PIWI domain is able to cleave the phosphodiester bond between position 10 and 11 measured from the 5 ' end of the siRNA [50], which is recognized by the Argonaute protein [47].

In A. thaliana there are 10 Argonute proteins. The founding member of the AGO gene family was discovered through the identification of Arabidopsis mutants that exhibit pleiotropic developmental defects. These mutants were coined as argonaute1 (AGO1) because their leaf defects resembled the tentacles of a small squid of the Argonauta genus [51]. AGO1 mutants were shown to be deficient in transgene silencing as well as they were hypersensitive to plant viruses [52]. Furthermore, AGO1 is playing a key role in miRNA regulated developmental processes [53]. Interestingly, AGO1 is negatively regulated by the miR-168 indicating that a proper balance is required for miRNA regulation in plants [28]. The catalytic activity of AGO2 was shown to be required for antiviral RNA silencing. Lack of AGO7 causes developmental defect similar to what is found in AGO1 mutants [54]. AGO4 and AGO6 play an important role in transcriptional silencing [41] [55]. 


\subsection{Viral suppressors of RNA silencing}

Plant viruses are efficient pathogens, which are able to infect and invade distinct plant species. The fact that most viruses have evolved RNA silencing suppressors underlines the antiviral nature of RNA silencing and reveals a pathogen counter defensive strategy. Viruses often cause severe symptoms, which suggests that the suppressor proteins are able to effectively disturb the RNA silencing pathways of the host. Many RNA silencing suppressors have been identified so far [56]. The various RNA silencing suppressors are able to target all effectors of the silencing pathway, such as viral RNA recognition, dicing, RISC assembly, RNA targeting and amplification (Figure 2.) .

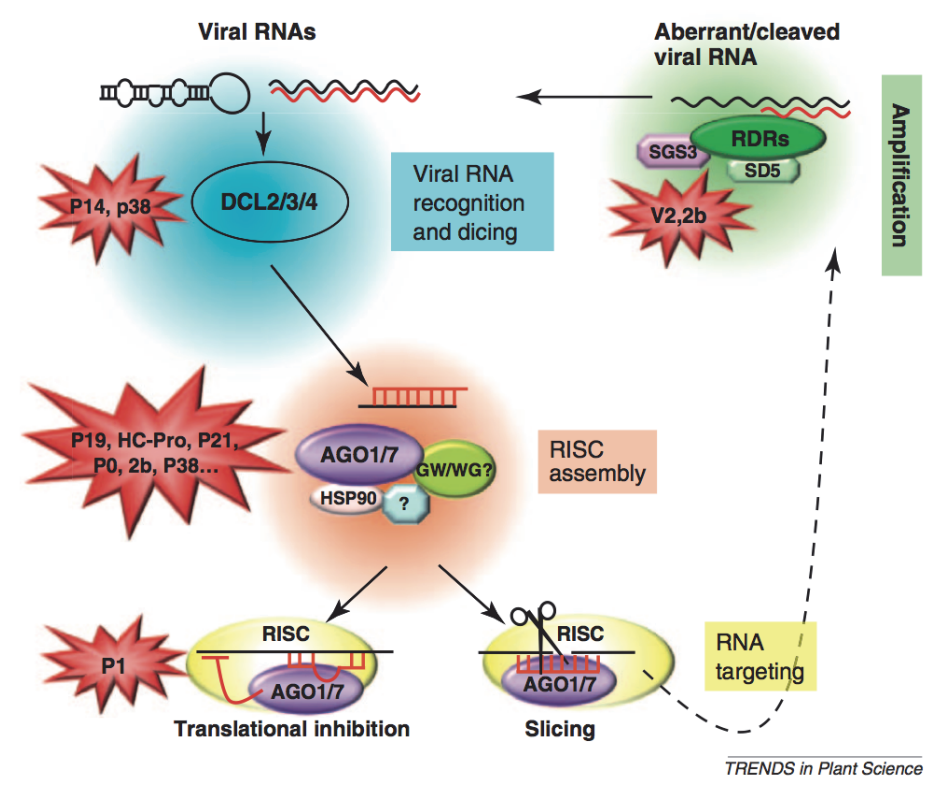

\section{Figure 2. Graphical}

representation of the antiviral RNA silencing in plants and its supression by virus-encoded silencing suppressors (From Burgyán and Havelda, 2011, Trends in Plant Science [56])

Inhibition of viral RNA recognition and dicing as a silencing suppressor strategy is known only in a couple of cases among plant viruses. The p14 of Photos latent virus and the p38 protein of the Turnip crinkle virus have dsRNA binding activity to interfere with DICER enzymes [57]. The V2 protein from Tomato yellow leaf curl virus binds the Arabidopsis SGS3 protein to interfere with the RDR6 mediated silencing amplification pathway [58].

RISC assembly can be prevented by siRNA sequestration. The p19 proteins of Tombusviruses bind $21 \mathrm{nt}$ siRNAs with high affinity [59].Tobacco etch virus HC-Pro (TEV Hc-Pro), Tobamovirus P122 and Tomato aspermy cucumovirus 2b protein also compromise RISC assembly by preventing si/miRNA incorporation [60] [61] [62]. 
Several silencing suppressors target AGO proteins. Most of them inhibit RISC assembly, such as $2 \mathrm{~b}$ protein of Cucumber mosaic virus [63]. The P0 protein of the phloemlimited poleroviruses also targets the AGO protein, the core component of the RISC and induces its degradation [64]. P0 has an F-box domain and targets small RNA unloaded AGO proteins. The p25 protein of Potato virus $X$ binds AGO proteins and facilitates their degradation via the proteasome pathway [65].

Interestingly, a sole RNA silencing suppressor has been identified so far that has the capacity to inhibit the preassembled RISC complex. The P1 protein of the Sweet potato mild mottle virus binds $\mathrm{AGO1}$ via its $\mathrm{WG} / \mathrm{GW}$ domains and hampers RISC activity by a yet unidentified mechanism [66] (Figure 2.).

However, suppressors can be grouped whether they inhibit RISC assembly or preassembled RISC complexes. Thus, suppressors impairing viral RNA recognition or dicing, sequestering small RNAs or directing AGO degradation, they all inhibit RISC assembly.

TRV, the type member of the Tobravirus group, has a bipartite genome consisting of single-stranded, positive sense RNAs. The larger genomic RNA, named RNA 1, contains four open reading frames (ORF). The first two ORFs encode a protein with a molecular weight of $134 \mathrm{~K}$ and a $194 \mathrm{~K}$ protein, which is produced by read-through translation of the $134 \mathrm{~K}$ gene. The two products are expressed directly from the viral genomic RNA and have a putative function in viral RNA replication. The third ORF encodes a $29 \mathrm{~K}$ protein with a role in cell-tocell movement of the virus. Finally, the 3'-end ORF encodes a small cysteine-rich $16 \mathrm{~K}$ protein having RNA silencing suppressor function. The $29 \mathrm{~K}$ and $16 \mathrm{~K}$ proteins are translated from subgenomic RNAs. The genomic RNA 2 contains the coat protein gene and the gene product determining the vector transmissibility [67]. 


\section{Aims}

More than 40 plant viral RNA silencing suppressors have been identified so far, however the exact working mechanism was determined for only a few of them. To better understand the working mechanism of Argonaute binding RNA silencing suppressors, the following aims have been set:

1. Characterization of the $16 \mathrm{k}$ silencing suppressor of the Tobacco rattle virus

2. Determination the minimal silencing suppressor domain of the Sweet potato mild mottle virus $\mathrm{P} 1$ protein

3. Restoring the AGO hook of the Sweet potato feathery mottle virus $\mathrm{P} 1$ protein 


\section{Materials and methods}

\subsection{Nicotiana benthamiana propagation}

Wild-type and GFP16c/RDR6i N.benthamiana plants grown in soil under normal growth conditions were used for, virus infection and agroinfiltration. Plants were grown in Phytotron (Versatile Enviromental Test Chambers; Sanyo, Tokyo Japan) under a $14 \mathrm{~h}$ light $(50 \mathrm{mE} \mathrm{m} \pm 2 \mathrm{~s} \pm 1)$ and $10 \mathrm{~h}$ dark regime at $23{ }^{\circ} \mathrm{C}$. The plants were infected with the CymRSV mutant Cym19stop virus to the sensor-based assay.

\subsection{Agroinfiltration}

Agroinfiltration was essentially carried out as described earlier [18]. Plasmid DNA was introduced into the Agrobacterium tumefaciens C58C1strain by triparental mating [68]. Agrobacterium strains harboring the expression plasmids were cultured at $28^{\circ} \mathrm{C}$ in $\mathrm{LB}$ medium in the presence of $5 \mu \mathrm{g} / \mathrm{ml}$ tetracycline and $100 \mu \mathrm{g} / \mathrm{ml}$ kanamycin. Cultures were centrifuged at room temperature with $1000 \mathrm{~g}$ to pellet the bacteria, then resuspended in the induction solution containing $10 \mathrm{mM}$ MES $\mathrm{pH}=5.6,10 \mathrm{mM} \mathrm{MgCl}_{2}$ and $150 \mu \mathrm{M}$ acetosyringone. Optical density of the cultures were determined and diluted to $\mathrm{OD}=0.3$ for suppressor and $\mathrm{OD}=0.1$ for reporter genes. Diluted and mixed Agrobacterium strains were incubated in the induction solution for 1-3 hours at room temperature before infiltration. 2-4 days incubation is needed to for infiltrated the plants.

\subsection{Western blot analysis}

To the blot analysis, samples were collected in $2 \mathrm{~cm}$ diameter. The samples were extracted in $5 \mathrm{x}$ loading puffer (1M Tris-HCl, 20\%SDS, 30\% glicerol, $10 \% \quad \beta$ mercaptoethanol, 60\% BP Blue) and boiled for 5 minutes. After sample preparation, 10\% SDS-PAGE was runned. Protein was transferred to PVDF membrane by hemidry blotting (1 hour $300 \mathrm{~mA}$ ) Aspecific binding was blocked in 5\% dry milk in PBS at every turn. Anti-HA (1:3000 in 5\% dry milk) and anti-GFP (1:5000) was used for HA and GFP tagged samples, respectively. Anti-rabbit HRP (1:5000) was used as secondary antibody. At the coimmunoprecipitation anti-Ha and anti-myc antibody was used (1:5000 in 2\% dry milk, secondary antibody was anti-rabbit HRPO (1:5000). 


\subsection{DNA construction and molecular cloning}

We prepared the $\mathrm{N}$ - terminal 360, 305, 210 and 120 amino acid containing versions of SPMMV $\mathrm{P} 1$ named $\mathrm{P} 1_{1-360} \mathrm{P} 1_{1-305}, \mathrm{P} 1_{1-210}$ and $\mathrm{P} 1_{1-120}$ respectively (Table 1.). These inserts were cloned into pSanyi to express them fusioned to a HA-tag at their N-terminal end.

\begin{tabular}{|l|l|}
\hline 5'GGGGATTCCCTAGAATGGGGAAATCCAAACTC3' & $\mathrm{P} 1$ 5'-end primer \\
\hline 5'TGAATTCTCATGCCACCGTGATGGGACACACCATAGC3' & $\mathrm{P} 1_{1-360} 3$ '-end primer \\
\hline 5'TGAATTCTCATGTCTTTGTAACCCACATAACTGC3' & $\mathrm{P} 1_{1-305} 3^{\prime}$ '-end primer \\
\hline 5'TGAATTCTCAAATTGAGAAAACAGTTTCCTCAAAAACC3' & $\mathrm{P} 1_{1-210} 3^{\prime}$-end primer \\
\hline 5'TGAATTCTCAGTTATCAAGTACATTGTCGTCGCGCTTGTT3' & $\mathrm{P} 1_{1-120} 3$ '-end primer \\
\hline
\end{tabular}

Table 1. Primes used in the truncated SPMMV P1 proteins study

SPFMV P1 RNA was isolated from SPFMV infected sweet potato plants (German Collection of microorganism and Cell Cultures). P1 of the SPFMV was amplified by degenerated primers, which primers included SPFMV P1 5' and $3^{\prime}$ ends (Table 2.). We made two mutagenesis in the perfect SPFMV P1 by QuickChange XL mutagenesis kit (Agilent Technologies). The histidine residue at position 109 and the tyrosine residue at position 139 were changed to tryptophan (Table 2.).

\begin{tabular}{|l|l|}
\hline GATGTCCTGGATGGATGGAAGTGTGACAGCTGC & 5' primer \\
\hline GCAGCTGTCACACTTCCATCCATCCAGGACATC & 3' primer \\
\hline CTAGAGCGTTAGGAGGGTGGGATGCATACTGTG & Histidine residue at positin 109 \\
\hline CACAGTATGCATCCCACCㄷCCCTAACGCTCTAG & Tyrosine residue at position 139 \\
\hline
\end{tabular}

Table 2. Primers used in the SPFMV P1 mutagenesis

P1 cDNA and mutants were checked by sequencing. The result was checked by blast analysis. Manipulation of every P1 DNA was carried out according to the standard procedures using commercially available restriction enzymes. DNA fragments were cloned into the agrobacterial expression plasmid pSanyi to be able to express an N-terminally HA-tagged protein. 


\subsection{Preparation of radioactively labeled DNA probe}

Linear double-stranded DNA was isolated then denatured by heat. Labeled singlestranded DNA was synthetized by the Hexa-Labeling Kit (Fermentas) in the presence of $\mathrm{P}^{32}$ dCTP as earlier described by Feinberg [69].

\subsection{Preparation of radioactively labeled RNA probe}

DNA corresponding to the probe was amplified by PCR using specific primers. The 5 '-end primer contained the sequence for the T7 promoter. Thus, the PCR product was fused with the T7 promoter. This PCR product was used to synthetize single-stranded RNA probe by the T7 RNA polymerase in vitro. Reaction contained $1 \times \mathrm{T} 7$ buffer, $0.5 \mathrm{mM}$ ATP, CTP, GTP, $0.05 \mathrm{mM}$ UTP and $\mathrm{P}^{32}$-UTP for one hour at $37^{\circ} \mathrm{C}$.

\subsection{RNA isolation}

Leaf tissue was frozen in liquid nitrogen then extracted in equal volume isolation buffer (200 mM Na-acetate $\mathrm{pH}=5.2,1.0 \%$ SDS and $10 \mathrm{mM}$ EDTA pH=8.0) and watersaturated phenol. Organic and non-organic phases were separated by high-speed centrifugation at room temperature for 5 minutes. Then the water phase was extracted with equal volume of phenol-chloroform and phases were separated as described above. RNA was precipitated by adding 2 volumes of $96 \%$ ethanol. RNA was sedimented by high speed centrifugation $\left(10\right.$ minutes at $\left.4{ }^{\circ} \mathrm{C}\right)$, pellet was washed with $70 \%$ ethanol then dried under vacuum. Finally, RNA was solubilized in sterile water [70].

\subsection{Northern blotting}

High molecular weight RNA was separated on $1.0 \%$ agarose, $2.2 \mathrm{M}$ formaldehyde and $1 \times$ MOPS containing gels. RNA was transferred to Hybond-N membrane in the presence of $20 \times$ SSC by capillary blotting for overnight. RNA was crosslinked to the membrane in an UV Stratalinker 1800 (Stratagene) using the 'autocrosslink' function. Membrane was prehybridized in PerfectHyb (Sigma-Aldrich) for 1 hour at $42{ }^{\circ} \mathrm{C} . \mathrm{P}^{32}$ labeled DNA probe was denatured by boiling then added to the hybridization reaction and incubated for overnight at $42{ }^{\circ} \mathrm{C}$. Washing the membrane was performed three times in $1 \times \mathrm{SSC}, 0.1 \%$ SDS at $65{ }^{\circ} \mathrm{C}$, then 
membrane was exposed to a storage phosphor screen (Molecular Dynamics Typhoon Phosphorimager, Amersham Biosciences).

\subsection{Small RNA blotting and hybridization}

RNA was separated on $12 \%$ poly-acrylamide and $8 \mathrm{M}$ urea containing vertical gels in the presence of $1 \times \mathrm{TBE}$. RNA was transferred onto Hybond-N membrane in the presence of $20 \times$ SSC by capillary blotting for overnight, then crosslinked as described above.

Membrane was prehybridized in PerfectHyb (Sigma-Aldrich) for 1 hour at $42^{\circ} \mathrm{C} . \mathrm{P}^{32}$ labeled RNA probe was denatured by boiling then added to the hybridization reaction and incubated for overnight at $42{ }^{\circ} \mathrm{C}$. Washing the membrane was performed three times in $1 \times \mathrm{SSC}, 0.1 \% \mathrm{SDS}$ at $42{ }^{\circ} \mathrm{C}$, then membrane was exposed to a storage phosphor screen (Molecular Dynamics Typhoon Phosphorimager, Amersham Biosciences).

\subsection{Immunoprecipitation}

Extracts for immunoprecipitation were prepared in IP buffer containing 30mM TRIS (pH 7.5), $150 \mathrm{mM} \mathrm{NaCl}, 5 \mathrm{mM} \mathrm{MgCl} 2,5 \mathrm{mM}$ DTT and $10 \%$ glycerol, then incubated for 1 hour at $4{ }^{\circ} \mathrm{C}$ with beads containing anti-HA antibody (Roche). The beads were then washed with IP buffer three times. Half of the eluates were used for RNA isolation using $400 \mu 12 \times P K$ buffer (200mM TRIS pH=7.5, $300 \mathrm{mM} \mathrm{NaCl}, 20 \mathrm{mM}$ EDTA pH=8.0), which was extracted by equal volume of phenol-chloroform. RNA was precipitated with 2 volume of $96 \%$ ethanol using $10 \mu \mathrm{g}$ of glycogen. The other half of the eluate was directly used for Western blotting. Commercially available antibodies were used for detecting GFP (Roche), HA-tag (Roche), myc-tag (Sigma). 


\section{Results}

\subsection{Characterization of the Argonaute binding 16K protein of the Tobacco rattle virus}

Tobacco rattle virus (TRV) infection is tightly under the control of the RNA silencing machinery as deduced by elevated TRV levels in plants in which RNA silencing components are genetically inactivated [71]. To counteract the effects of this natural host defense response, TRV has the ability to suppress RNA silencing. In plants, $16 \mathrm{~K}$ protein of TRV suppresses RNA silencing induced by ssRNA as well as low concentration of double-stranded RNA, and reduces the accumulation of siRNAs in both transient and stable expression assays [72] [73]. 16K interferes with cell-to-cell movement and systemic propagation of silencing but not transitive RDR-dependent amplification of RNA silencing [72] .

During the course of collaboration, our partners wanted to deepen into the mechanism of suppression of $16 \mathrm{~K}$ protein. Moreover, $16 \mathrm{~K}$ failed to bind synthetic small RNAs. They also proved that the cysteine-rich motifs at the N-terminus of $16 \mathrm{~K}$ were required for silencing suppression. However, 16K protein physically associated with AGO1, AGO2 and AGO4, suggesting that this interaction may compromise RISC assembly (Dr. César Llave, personal communication).

Using the standard agroinfiltration assay with the 35S-GFP reporter leads to the de novo formation RISC complexes. DsRNA and siRNA duplex-binding silencing suppressors impair target cleavage activity by inhibiting RISC assembly. To be able to identify and characterize RNA silencing suppressors that inhibit the activity of programmed RISC (active RISC), we used recently developed sensor-based assays [61].

Plants were infected with the CymRSV mutant Cym19stop, which triggers RNA silencing in upper leaves. These leaves are resistant to challenge inoculation by viruses with sequences homologous to the primary virus, indicating that they contain active RISC complexes [74]. To analyze the activity of CymRSV-activated RISC and suppressor effects on this activity, GFP-Cym sensor RNAs and suppressor proteins were analyzed in Cym19stop-infected N. benthamiana plants. SiRNA sensor constructs contained a GFPencoding ORF fused to a sequence of $194 \mathrm{nt}$ of CymRSV (GFP-Cym) or $204 \mathrm{nt}$ of PoLV 
(GFP-PoLV) (Figure 3.). The PoLV sensor construct was used as a negative control, as it does not contain sequence similarity to CymRSV (Figure 3.).

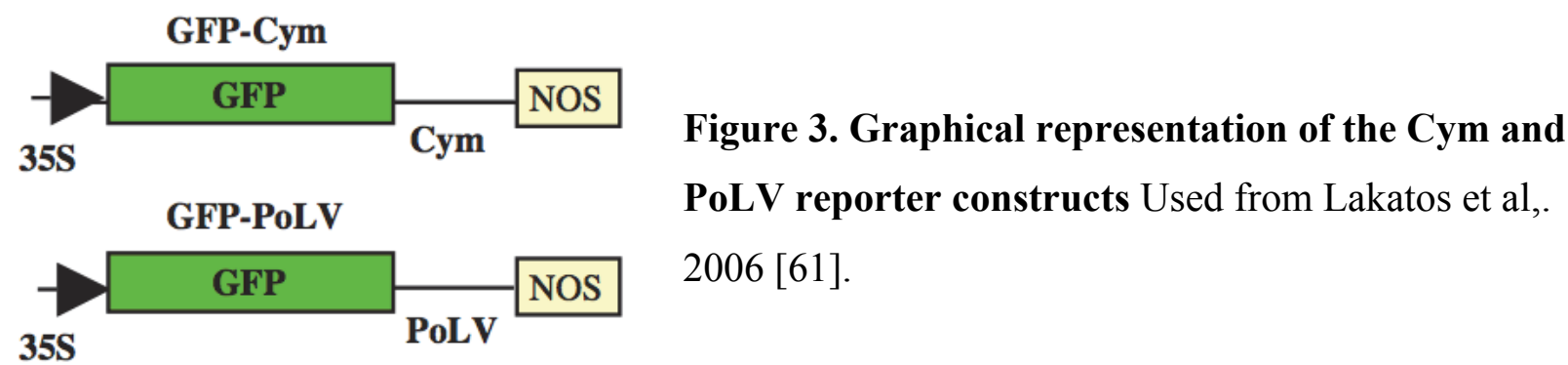

Nonsymptomatic leaves emerging 14-18 days after inoculation with Cym19stop contain de novo RISC complexes loaded with viral siRNAs. Then, these leaves were coinfiltrated with Agrobacterium strains carrying the GFP-Cym or GFP-PoLV sensor and $16 \mathrm{~K}$ cDNA constructs. SPMMV P1 was used as a positive, while HC-Pro was used as a negative control [66].

2 days after infiltration, GFP fluorescence in patches expressing the GFP-Cym sensor was compared to fluorescence in patches expressing the GFP-PoLV sensor, and GFP mRNA and protein accumulation was analyzed by RNA gel blot hybridization and immunoblotting. Loss of GFP-Cym sensor activity was detected in the presence of $16 \mathrm{~K}$ suppressor in infected plants (Figure 4.).

Consistently, the amount of GFP protein was significantly lower from the GFP-Cym sensor than from the GFP-PoLV sensor (Figure 4.A). Moreover, a GFP-specific RNA shorter than the predicted sensor mRNA transcript was detected in RNA samples recovered from GFP-Cym, but not GFP-PoLV-infiltrated patches co-infiltrated with 16K and HC-Pro (Figure 4.B). As expected, SPMMV P1 inhibited viral siRNA loaded preassembled RISC, which was indicated by the increased fluorescence in infiltrated patches and the lack of shorter GFP derived cleavage product on Northern blot.

To examine effect of $16 \mathrm{~K}$ protein on miRNA-programmed RISC activity, we used the second in vivo test system developed [61]. This assay takes advantage of the fact that miR171 exists in fully developed $N$. benthamiana leaves in active RISC complexes. 
Thus, lack of inhibitory capacity of an RNA silencing suppressor to active RISC results in degradation of the mRNA transcribed from the sensor and reduced GFP accumulation (Figure 5.)

A
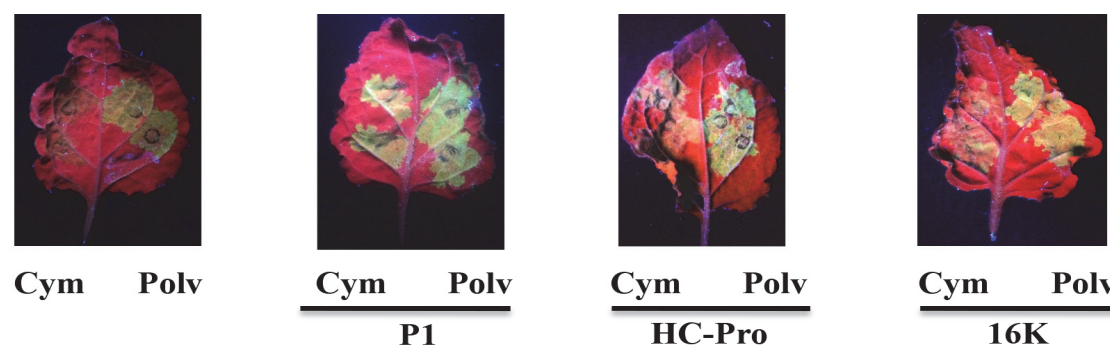

$\frac{\text { Cym Polv }}{\text { HC-Pro }}$

$\frac{\text { Cym Polv }}{16 K}$

Cym19S infected
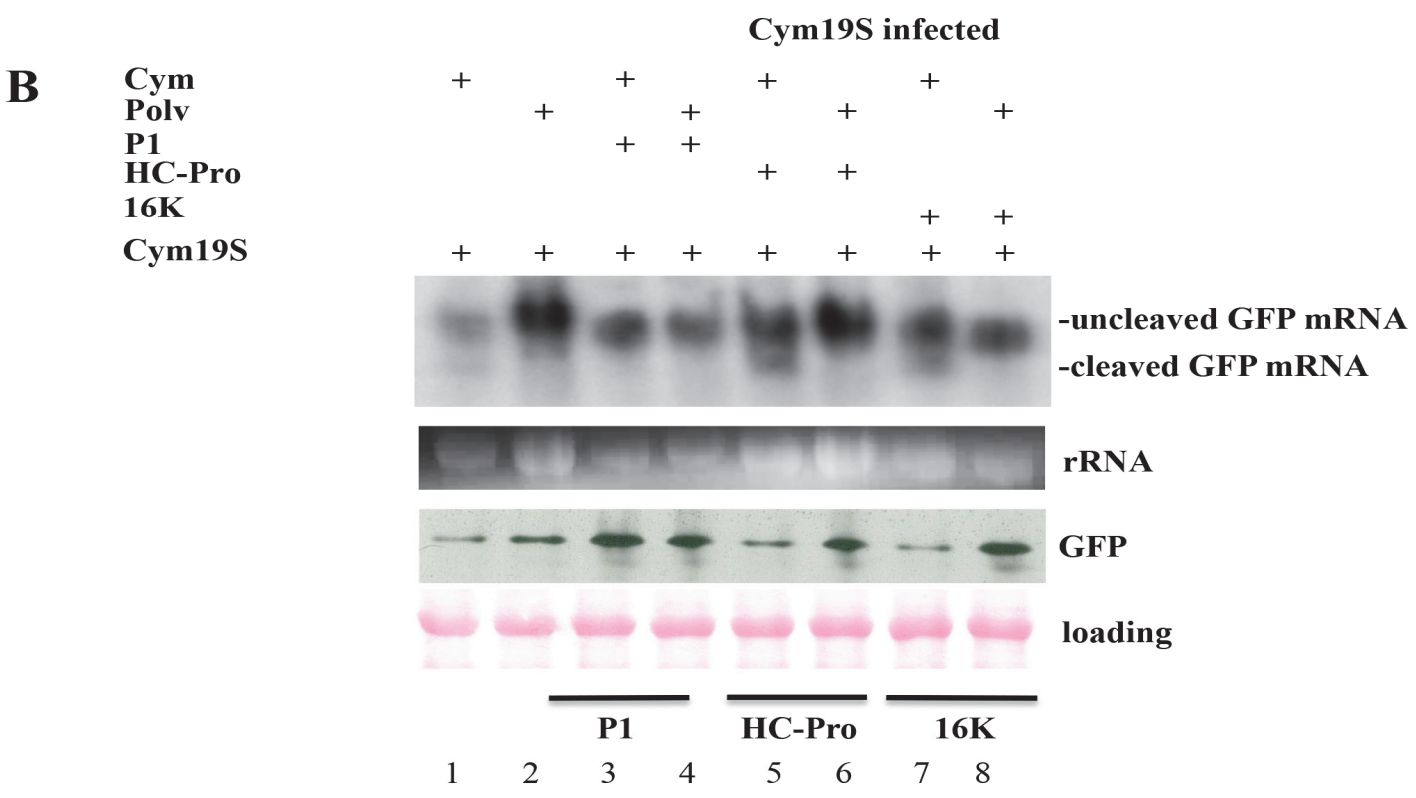

Figure 4. 16K of TRV does not inhibit siRNA loaded preassembled RISC A. Infected leaves infiltrated with Cym- and PoLV-GFP and the $16 \mathrm{~K}$ expressing constructs. B. Analysis of GFP expression at mRNA and protein level in infiltrated patches. Top panel shows Northern analysis of GFP expression. Second panel is an RNA loading control. Third panel is the analysis of GFP protein expression. Fourth panel shows protein loading control.

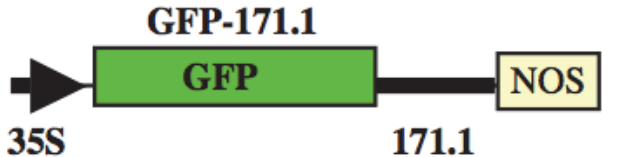

171.1
Figure 5. Graphical representation of the GFP171.1 reporter construct 
Agrobacterium co-infiltration experiments were carried out using a GFP-171.1 sensor co-infiltrated with 16K of TRV. SPMMV P1 was used as a positive, while HC-Pro was used as a negative control [66]. GFP fluorescence and protein accumulation was reduced in patches expressing the GFP-171.1 sensor compared to patches expressing the GFP-171.1+SPMMV P1 constructs. In the case of GFP-171.1+16K infiltrated patches, either GFP fluorescence or GFP protein level were much lower than in GFP-171.1+SPMMV P1 patches indicating that 16k, similarly to TEV HC-Pro, is not able to inhibit preassembled RISC complexes (Figure 6). Similarly, accumulation of GFP-171.1 sensor transcripts were reduced in empty vector, $16 \mathrm{~K}$ and HC-Pro infiltrated patches.

In summary, using two assays we demonstrated that the AGO binding $16 \mathrm{~K}$ protein of TRV could not inhibit the activity of preassembled RISC complexes.

A

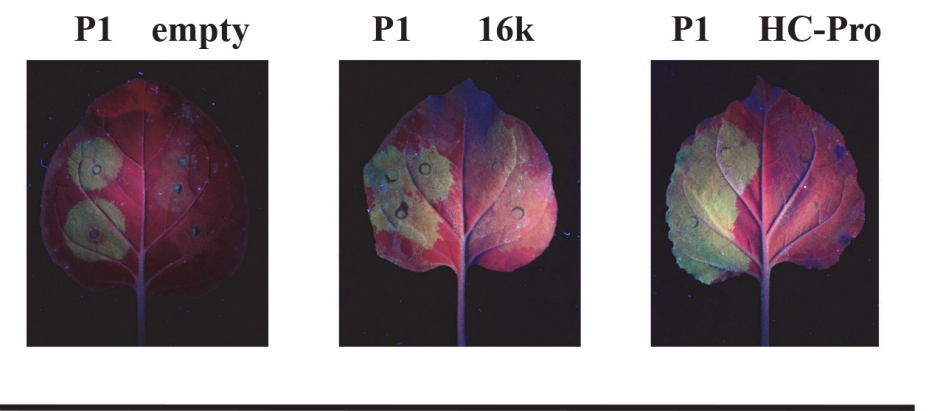

B

GFP-171.1
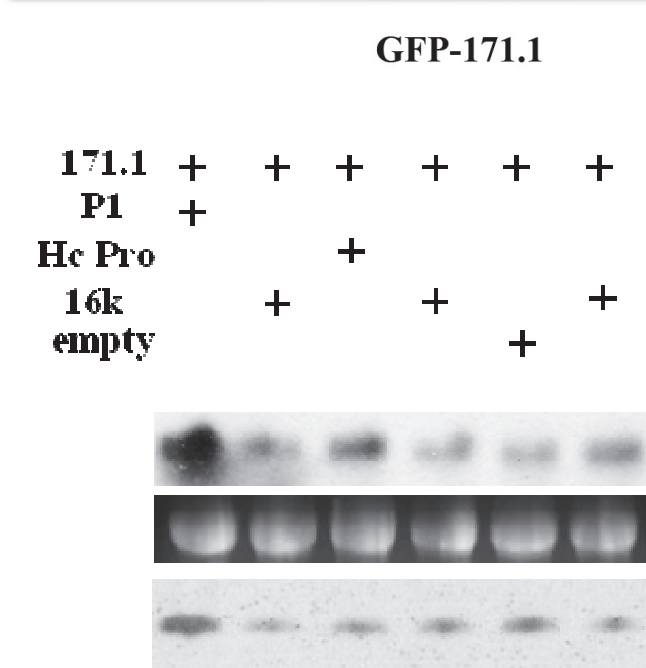

$-\infty \leq-\infty \leq$ loaling

$\begin{array}{llllll}1 & 2 & 3 & 4 & 5 & 6\end{array}$

\section{GFP}

Figure 6. 16K of TRV does not inhibit miRNA loaded preassembled RISCA Leaves infiltrated with GFP-171.1 and the $16 \mathrm{~K}$ expressing constructs. B. Analysis of GFP expression at mRNA and protein level in infiltrated patches. Top panel shows Northern analysis of GFP expression. Second panel is an RNA loading control. Third panel is the analysis of GFP protein expression. Fourth panel shows protein loading. 


\subsection{Narrowing the silencing suppressor domain of Sweet potato mild mottle virus $\mathrm{P} 1$ protein}

It was recently found that the P1 protein but not HC-Pro of SPMMV (family Potyvirideae, genus Ipomovirus) has silencing suppressor activity. In vivo transient expression of sensor constructs showed that P1 protein, the RNA silencing suppressor of SPMMV, clearly interferes with single stranded (ss) mi- and siRNA driven RISC activity by inhibiting target RNA cleavage (active RISC, effector step of RNA silencing). Consistently, it was found that P1 cofractionated with AtAGO1 and small RNAs in a $>669 \mathrm{kD}$ complex. Furthermore, immunoprecipitation studies showed that P1 targets RISC and binds Argonaute protein, the catalytic subunit of RISC complexes. Mutational analysis revealed three WG/GW motifs, resembling the Argonaute binding platform conserved in plants and metazoans, at the $\mathrm{N}$-terminal part of $\mathrm{P} 1$, which are required for AGO binding. Thus, P1 protein is the only silencing suppressor yet that inhibits active RISC and it was first demonstrated that a WG/GW protein has negative effect on RNA silencing [66].

\subsection{Appearance of C-terminally truncated SPMMV P1 proteins in planta}

It was demonstrated that the N-terminal 383 amino acid region of SPMMV P1 possessed the silencing suppressor domain [66]. If the N-terminally HA-tagged the full length SPMMV P1 was infiltrated into $N$. benthamiana plants and immunoprecipitated, the minority of the HA-tagged proteins were proven full length, as our western blotting analysis showed (Figure 7).

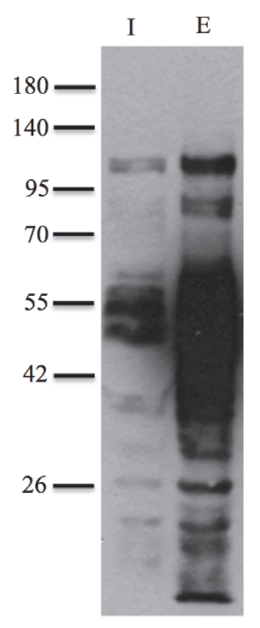

Figure 7. SPMMV P1 is degraded in planta I stands for input, E stands for eluate of immunoprecipitation Molecular weight is shown in $\mathrm{kDa}$ 
This result might not be surprising, since it is already known that maturation of the huge potyviral polypeptide translated occurs via the intrinsic protease activities of the polypeptide. Even $\mathrm{P} 1$ has a protease domain in its $\mathrm{C}$ - terminal end, which is required for liberation of $\mathrm{P} 1$ from the primary translation product [75]. Thus, the $\mathrm{C}$-terminal truncation of P1 can be a consequence of its own protease activity, but the action of the plant proteases could not be excluded. However, the primary aim of our study was to whether these shorter versions of P1 still have RNA silencing suppressor activity. To answer this question, we systematically performed C-terminal truncations on the SPMMV P1 protein. Thus, we prepared the $\mathrm{N}$ - terminal 330, 251 and 210 amino acid containing versions of SPMMV P1 named $\mathrm{P} 1_{1-360} \mathrm{P} 1_{1-305}, \mathrm{P} 1_{1-210}$ and $\mathrm{P} 1_{1-120}$ respectively. These inserts were cloned into pSanyi to express them fusioned to a HA-tag at their N-terminal end. Agrobacteria strains harboring these constructs were co-infiltrated with reporter construct GFP-171.1 [76] to check for silencing suppressor activity [66]. SPMMV P1 $1_{1-383}$ was used as a control, because this is known silencing suppressor. 48 hours post infiltration, visual inspection showed bright green fluorescence for both the control and the shorter versions of P1 proteins indicating that even the $\mathrm{P} 1_{1-210}$ protein still had a strong RNA silencing suppressor activity, but not $\mathrm{P} 1_{1-120}$. Taken together, we located the silencing suppressor domain of the 759 amino acid SPMMV P1 protein at its N-terminal 210 amino acid region. We propose that this shorter version will be useful for further investigations. (Figure 8.)

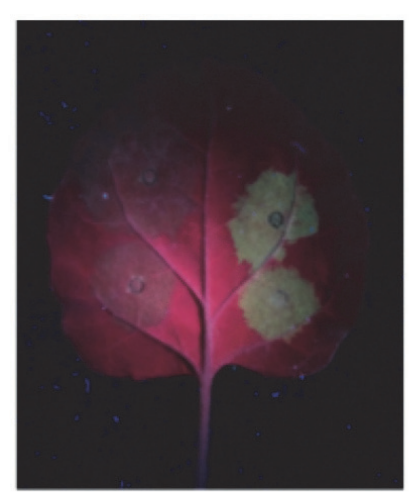

empty P1 1-383

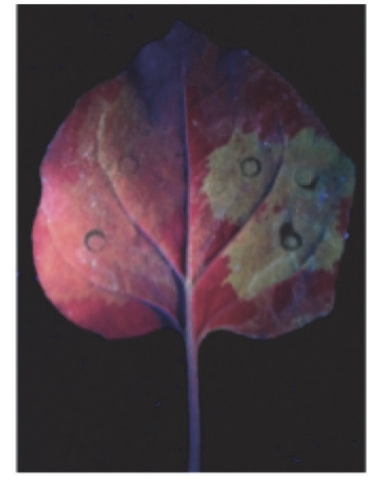

P1 1-120 P1 1-383

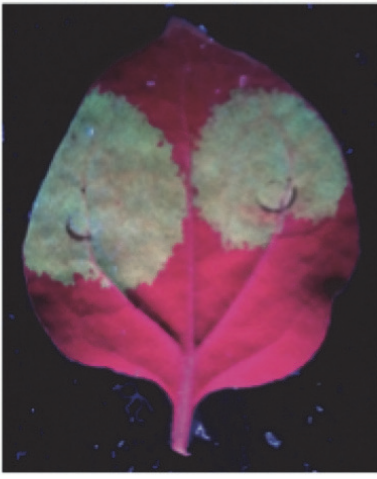

P1 1-210

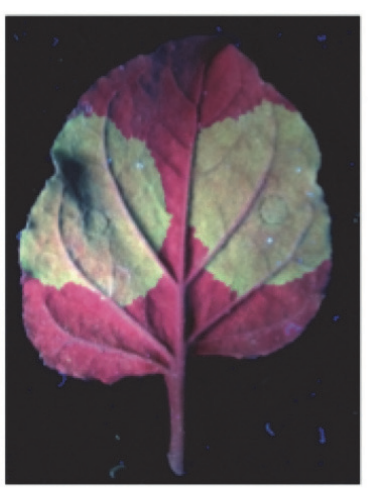

P1 1-360 P1 1-383

Figure 8. RNA silencing suppressor activity of the truncated mutants The first panel shows empty vector infiltrated sample, used as negative control. The mutant of interest was infiltrated as shown in the second and third panel. The last panel shows the $\mathrm{P} 1_{1-383}$ control. 
Western blotting was carried out to detect GFP protein in the infiltrated leaves. Consistently with our visual inspection, strong GFP expression was found in the protein extracts of $\mathrm{P} 1_{1-383}, \mathrm{P} 1_{1-360}, \mathrm{P} 1_{1-305}, \mathrm{P} 1_{1-210}$ infiltrated leaves, while significantly less GFP was detected, when GFP-171 or GFP-171 and P1 $1_{1-120}$ were infiltrated (Figure 9A). These experiments clearly revealed that silencing suppressor function was lost in the case of the $\mathrm{P} 1_{1}$ 120 mutant. Finally, the expression of the N-terminally HA-tagged truncated silencing suppressor proteins were examined by western blotting. Our result showed high suppressor expression in increasing protein size (Figure 9B). On the other hand, leaves infiltrated with $\mathrm{P} 1_{1-120}$ did not express the corresponding protein. Of note, that extracts used in this experiment contained nearly the same amount of protein, as shown in the protein loading panel (Figure 9B).

A

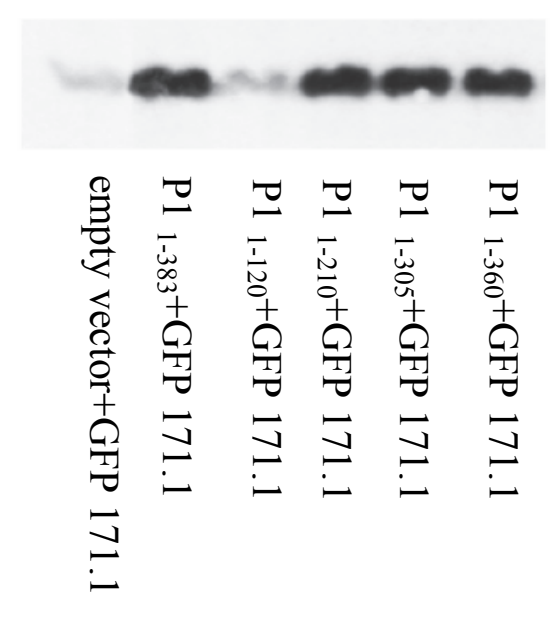

B

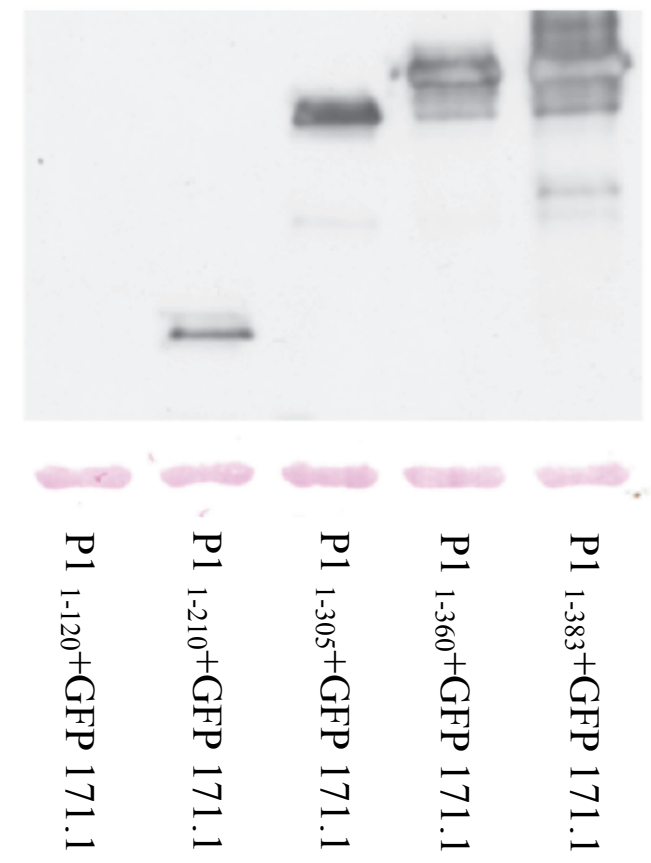

Figure 9. Expression analysis of GFP and the truncated suppressor mutant (A) GFP was detected by anti-GFP polyclonal antibody (B) Suppressor mutants were detected by anti-HA antibody (Roche). Lower panel represents loading control 


\subsection{P1 protein of the Sweet potato feathery mottle virus is the closest homologue of SPMMV P1}

According to databank searches and previous studies [75], the P1 protein of the Sweet potato feathery mottle virus (SPFMV) (family Potivirideae, genus Potyvirus) showed remarkable homology to the P1 protein of SPMMV. Our group has a longstanding interest in better understanding the role of both the viral and cellular WG/GW proteins. Therefore, we decided to isolate and characterize the P1 protein of SPFMV. Since several earlier showed that the HC-Pro protein of the Potyvirus genus was described to have RNA silencing suppressor activity, we also aimed to isolate the HC-Pro of SPFMV.

Therefore, BLAST searches were performed to collect P1 and HC-Pro sequences to design primers for PCR. Our results on the homology searches showed that the P1 cistron of SPFMV was more heterogenous than the HC-Pro cistron. Therefore the primer pairs for P1 designed to be are more degenerated than for HC-Pro (Figure 10.).

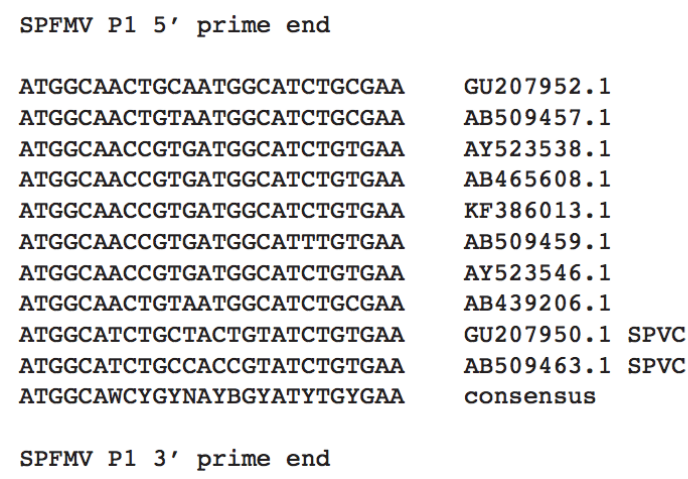

GU207952.1

AB509457. 1

AY523538.1

$\mathrm{AB} 465608.1$

$\mathrm{KF} 386013.1$

AB509459.1

AY523546.1

$\mathrm{AB} 439206.1$

GU207950.1 SPVC

AB509463.1 SPVC

consensus

D86371.1 $\mathrm{AB} 439206.1$ AB509459.1 consensus

D86371.1 FJ155666.1 AB439206.1 consensus
AY523546. 1 $\mathrm{AB} 439206.1$ AB509459.1 FJ155666.1 AY523538.1 consensus
Figure 10. Design of degenerated primers for P1 and HC-Pro cistrons of SPFMV Collection of 5' prime and 3' end sequences of P1 and HC-Pro cistrons, which were used to determine the consensus sequence. Genbank accession numbers are on the right side. Of note, in 2010 GU207950.1 and AB509463.1 were still classified as SPFMV, not as Sweet potato virus $C$ (SVPC). 
Consensus sequence was used to design primers to amplify the corresponding cistrons of SPFMV. To amplify the corresponding cistrons of SPFMV, we used total RNA isolated from SPFMV infected Sweet potato plants, purchased from the German Collection of Microorganisms and Cell Cultures. Total RNA was reverse transcribed using AMV reverse transcriptase with random nonamer oligonucleotides, then used in PCR reactions. As Figure 11. shows, a strong PCR product about 2000-2100 nt in size could be seen in the PCR reaction, when we used the P1 primer pair. A PCR product about 1400-1600 nt was detected in the HC-Pro primers driven PCR reaction (Figure 11.). These two PCR fragments were isolated from the agarose gel and cloned into the TOPO 2.1 vector. Several independent positive colonies were picked up from the cloning reactions to isolate plasmid DNA for nucleotide sequence determination. Results of the initial sequence determination revealed that all sequenced clones corresponded to P1 and HC-Pro cistrons. Thus, we determined the entire nucleotide sequence of two independent clones for both cistrons. Sequence analysis of the P1 cistron showed $85-96 \%$ similarity to the P1 sequences in the database. The deduced amino acid sequence of the P1 cistron consists of 698 amino acids. The overall identity between SPFMV and SPMMV P proteins was $24.6 \%$. Interestingly, the first 193 amino acid region of SPFMV P1 showed $41.6 \%$ amino acid identity to the corresponding part of the SPMMV P1. As it was shown for SPMMV P1, the very N-terminal part of the protein possesses the AGO binding domain [66].

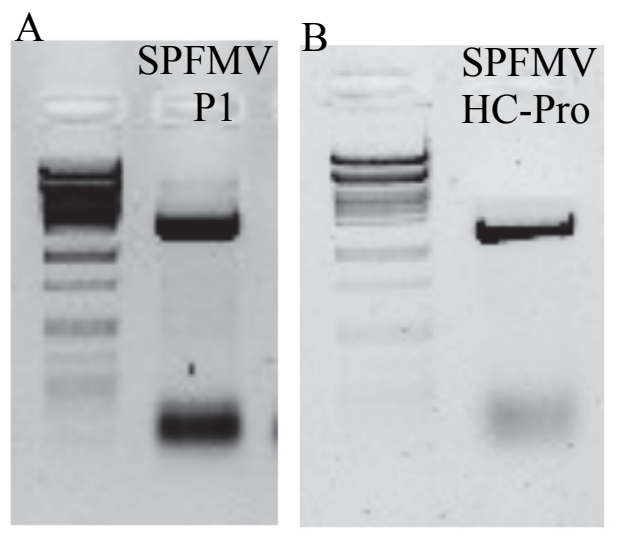

Figure 11. RT-PCR amplification of the SPFMV cistrons of interest A Amplification of SPFMV P1 resulted a fragment of $2100 \mathrm{bp}$ in size. B. Amplification of SPFMV HC-Pro resulted a DNA fragment of $1500 \mathrm{bp}$ in size

Pairwise comparison with ClustalW also showed that SPFMV P1 has only one GW/WG domain compared to SPMMV P1. The first WG/GW at position 25 and the surrounding amino acids are well conserved between SPFMV and SPMMV. Moreover, there 
is a His $(\mathrm{H})$ residue at position 109 and a $\operatorname{Tyr}(\mathrm{Y})$ residue at position 139, which correspond to the Trp (W) 101 and 131 in the SPMMV protein (Figure 12.).

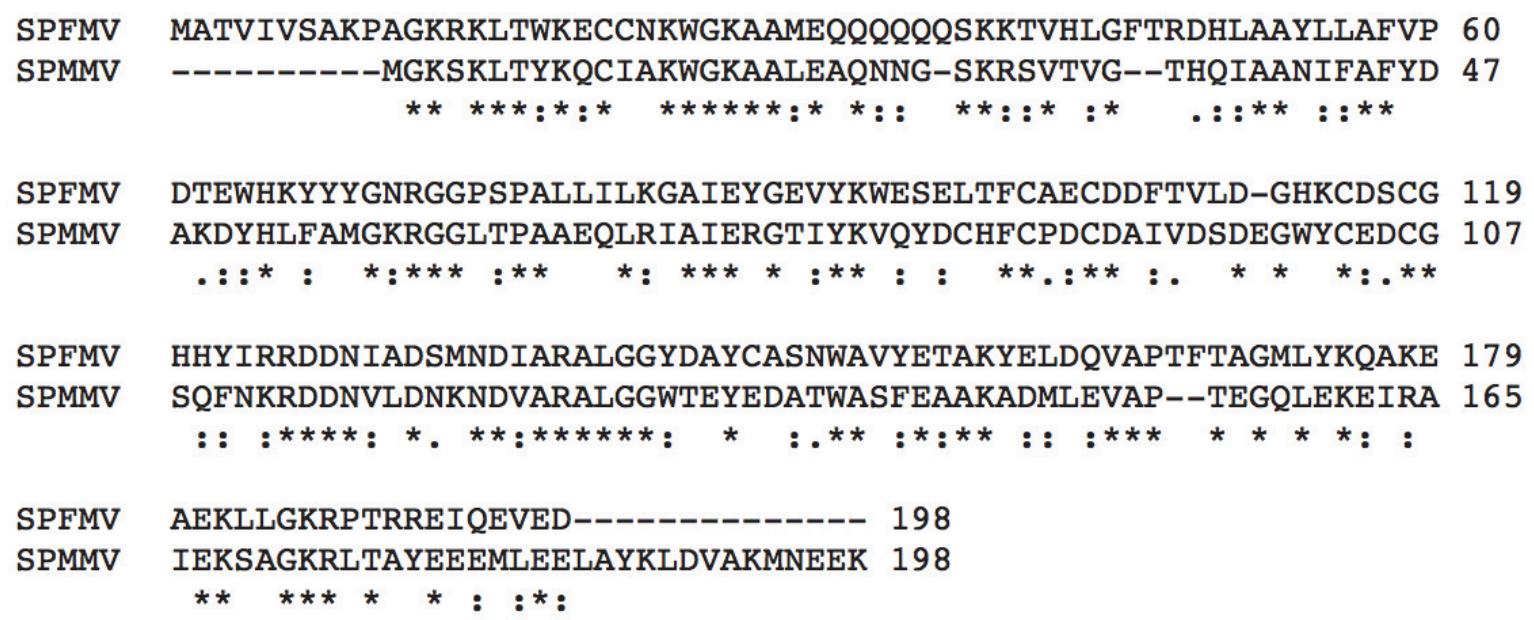

Figure 12. Pairwise comparison of P1 protein of SPFMV and SPMMW To compare the N-terminal regions of SPFMV and SPMMV P1 proteins, CLUSTALW alignement was used.

Sequence analysis of the HC-Pro cistron showed that it consists of $1374 \mathrm{bp}$. The deduced amino acid sequence revealed a 458 amino acid protein showing 91-97\% homology to the known SPFMV HC-Pro proteins. Of note, that the HC-Pro of SPFMV contains the FRNK motif was shown to be essential for siRNA binding and RNA silencing suppressor activity [77].

\subsection{Functional analysis of SPFMV P1 and HC-Pro}

We also wanted to check if the SPFMV P1 and HC-Pro had an RNA silencing suppressor activity. To do this, P1 and HC-Pro were cloned into an agrobacterial expression vector. Introduction of inserts into pSanyi allows the expression of the ORF of interest fused to a haemagglutinin epitope at the N-terminal or the C-terminal end of the protein [78]. Both P1 and HC-Pro were cloned into pSanyi to have an N-terminal HA-tag. To make a functional RNA silencing suppressor assay, we used the standard co-infiltration approach [18]. Agroinfiltration is a powerful method to transiently express proteins in $N$. benthamiana at high level. When an Agrobacteria strain is introduced into the leaves of $N$. benthamiana by infiltration, the gene of interest with the regulatory regions is transferred from the bacteria to 
the genome of the plant. Almost every cell of the infiltrated region contains the transgene at high copy number. The several hundred copies of the transgene results in high level of gene expression, which strongly initiates RNA silencing leading to downregulated gene expression at the level of RNA in 3-6 days. Co-infiltration of an RNA silencing suppressor with the gene of interest results in enhanced and sustained expression of the gene expression. This approach is used for standard screening of RNA silencing suppressors in planta, which works irrespectively of the mechanism of the silencing suppressor [79].

Agrobacteria strain harboring the $35 \mathrm{~S}-\mathrm{GFP}$ as a reporter gene was co-infiltrated with the SPFMV proteins of interest into $N$. benthamiana leaves. HA-tagged SPMMV P1 was used as a control in our experiments. 3 days post-infiltration (dpi) visual inspection of the infiltrated leaves was carried out under UV light. We found that SPMMV P1 but not the empty vector strongly suppressed RNA silencing, which could be seen as bright green fluorescence in the infiltrated patches. However, neither SPFMV P1, nor SPFMV HC-Pro suppressed RNA silencing, which could be anticipated from the lack of the green fluorescence at the right sides of the infiltrated leaves (Figure 13.).

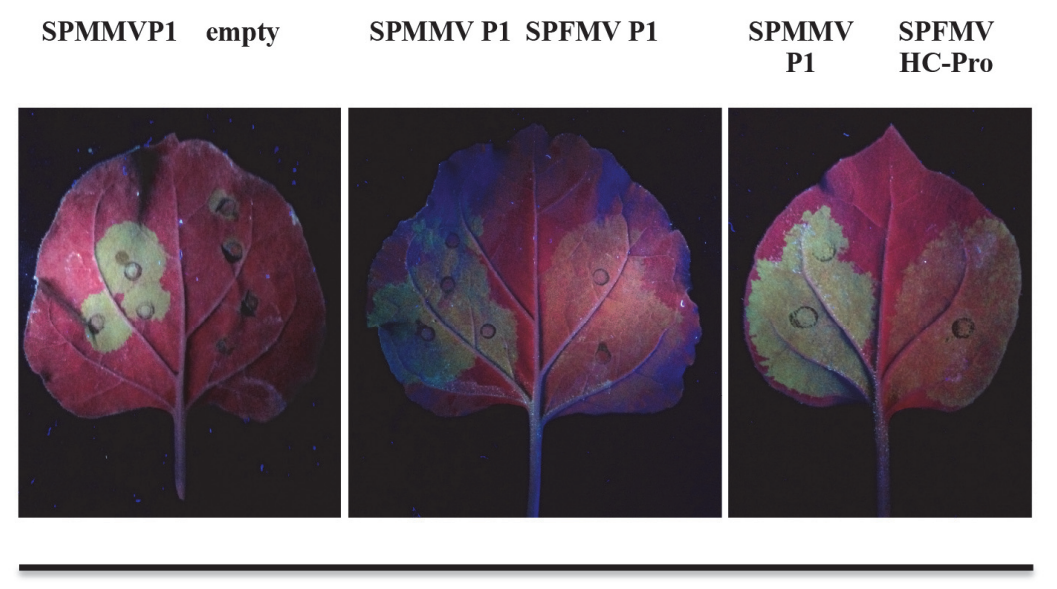

35S-GFP Figure 13. Functional
analysis of SPFMV P1
and HC-Pro The left sides
of the leaves were
infiltrated with SPMMV
P1. Left side with empty
vector, SPFMV P1, or
SPFMV HC-Pro

RNA and protein were isolated from the infiltrated patches to perform gene and protein expression studies. Northern blotting showed that GFP mRNA was found at much lower amount in samples isolated from SPFMV P1 and HC-Pro infiltrated leaves than in SPMMV P1 control samples. In agreement, GPF protein level was much higher in those 
samples where silencing was suppressed (SPMMV P1) than in samples, in which RNA silencing degraded GFP mRNA (Figure 14.).

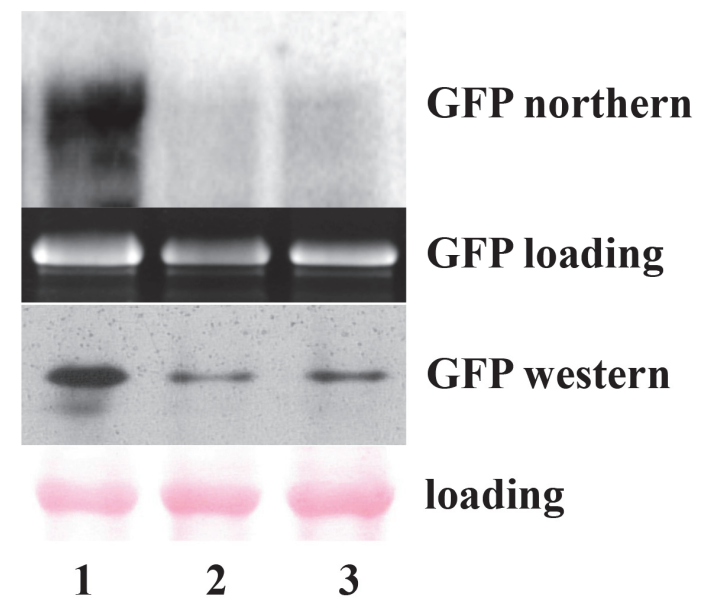

Figure 14. Expression analysis of GFP at the mRNA and protein level Top panel shows Northern analysis of GFP expression. Second panel shows RNA loading control. Third panel for immunological detection of GFP protein. Panel four shows Ponceau staining used as loading control.

There might be at least two possible explanations for the lack of silencing suppressor activity of SPFMV P1 and HC-Pro. The first one is, that the proteins may not have intrinsic RNA silencing suppressor activity. Another explanation could be the poor or no expression of the proteins of interest, which can be due to the inappropriate expression construct. In agreement, the level SPFMV P1 and HC-Pro proteins were checked by Western blotting. Our results showed that there was no protein expression (data not shown). To see if this phenomenon is due to lack of RNA silencing suppressor activity or lack of protein expression for another unknown reason, we co-infiltrated Agrobateria strains harboring SPFMV P1 and HC-Pro with the strong RNA silencing suppressor HC-Pro of Tobacco etch virus (TEV) into $N$. benthamiana leaves.

At 3 dpi, samples were collected and protein expression was checked by Western blotting. Our results showed a remarkable expression of both SPFMV P1 and HC-Pro in the presence of TEV HC-Pro suggesting that our expression construct seemed to be adequate for protein expression (Figure 15.). Thus, most probably the lack of intrinsic silencing suppressor activity was the reason why neither SPFMV P1 nor HC-Pro were expressed without coexpression with a strong RNA silencing suppressor.

In summary, we established that neither SPFMV P1 nor HC-Pro proteins showed RNA silencing suppressor activity. 


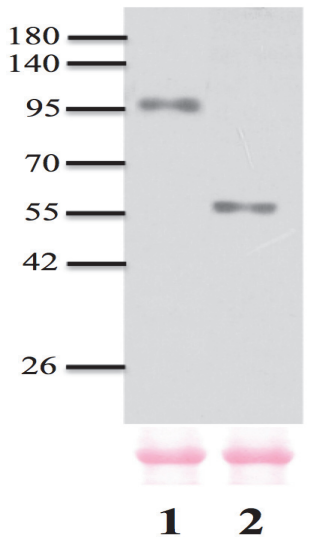

Figure 15. Detection of SPFMV proteins of interest Western blotting of SPFMV P1+TEV HC-Pro (lane 1) and SPFMV HC-Pro+TEV HC-Pro (lane 2) infiltrated leaves. HA-antibody was used for detection. Ponceau staining was used as loading control.

\subsection{Restoring the Argonaute binding domains of SPFMV P1}

Our results revealed that the SPFMV P1 bearing only one WG/GW motif did not have RNA silencing suppressor activity. Earlier studies on SPMMV P1 showed that at least two WG/GW domain were required for silencing suppressor activity. We hypothesized, therefore, that the sole WG/GW motif in wild type SPFMV P1 might be insufficient for silencing suppressor activity. Due to the high degree of amino acid identity between the SPFMV and SPMMV P1 proteins at their N-terminal ends, we determined amino acids in SPFMV P1 corresponding to the tryptophan residues of the second and third WG/GW motifs in SPMMV P1 (Figure 16.). The histidine residue at position 109 and the tyrosine residue at position 139 were changed to tryptophan using the QuikChange XL mutagenesis kit. Thus, three mutants, H109W, Y139W, and H109W/Y139W, were created, resulting in one additional WG/GW motif in the first two mutants, and two additional WG/GW motifs in the third. Mutants were cloned into the agrobacterial expression plasmid pSanyi to be able to express an N-terminally HA-tagged protein [78]

19-KECCNKWGKAAMEQQ-33

9-KQCIAKWGKAALEAQ-23
107-D---GHKCDSCGH-116

96-DSDEGWYCEDCGS-108
131-DIARALGGYDAYCAS-145 SPFMV

123-DVARALGGWTEYEDA-137 SPMMV

Figure 16. Determination of amino acids in SPFMV $P 1$ corresponding to $W$ residues in SPMMV P1 WG/GW duplets were underlined. 


\subsection{Functional analysis of the SPFMV P1 mutants}

To check the RNA silencing suppressor activity of the mutants, the standard agroinfiltration assay was used. SPMMV P1 was used as positive control, while the wild type SPFMV P1 was used as a negative control. Agrobacteria strains harboring the controls and the SPFMV P1 mutants were co-infiltrated with 35S-GFP into leaves of $N$. benthamiana. At 3 dpi, visual inspection of the infiltrated leaves was carried out. Figure 17 shows that SPMMV P1 did indeed, and wild type SPFMV P1 did not inhibit RNA silencing indicating that our assay worked properly. Our results showed very low GFP activity in the patches infiltrated with H109W and H139W mutants, which could be due to the lack of RNA silencing suppressor activity. Interestingly, the double mutant P1 H109W/Y139W revealed remarkable silencing suppressor activity according to the visual inspection (Figure 17.).
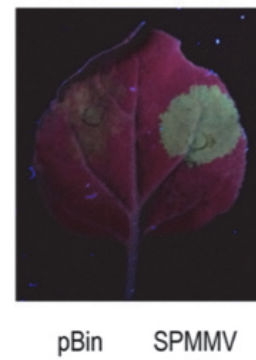

P1

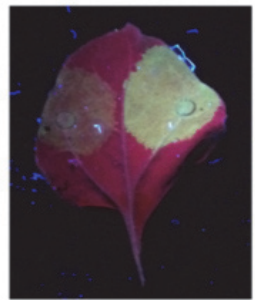

SPFMV P1 SPMMV

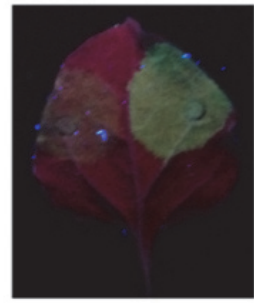

SPFMV P1 SPMMVP1 H109W

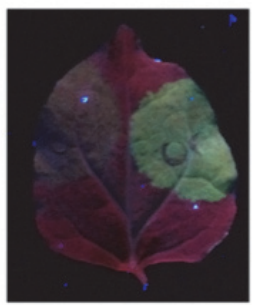

SPFMVP1 SPMMVP1 SPFMVP1 SPMMVP1 Y139W

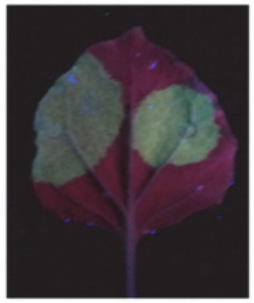

H109W/139W

35S-GFP

Figure 17. The double SPFMV P1 mutant possesses RNA silencing suppressor activity

The right side of each leave was infiltrated with the positive control (SPMMV P1). P1 constructs were co-infiltrated with 35S-GFP. The GFP fluorescence of the mutant of the interest was compared to SPMMV P1. Bright green fluorescence indicates silencing suppressor activity.

Moreover, expression analysis of GFP at the mRNA level showed a very low GFP expression for the wild type SPFMV P1 and the H109W and Y139W mutants, which support our visual inspection. GFP expression was much higher in RNA samples isolated from SPMMV P1 and SPFMV P1 H109W/Y139W double mutant indicating a comparable level of RNA silencing suppression. Consistently, GFP protein expression was low in wild type SPFMV P1 and the H109W and Y139W mutant samples, while GFP expression was as high in the SPFMV P1 H109W/Y139W double mutant, as in the SPMMV P1 sample we used as 
positive control. Consistently with our previous results, silencing suppressor activity of the SPFMV P1 H109W/Y139W double mutant could be detected by Western blotting. (Figure 18.)

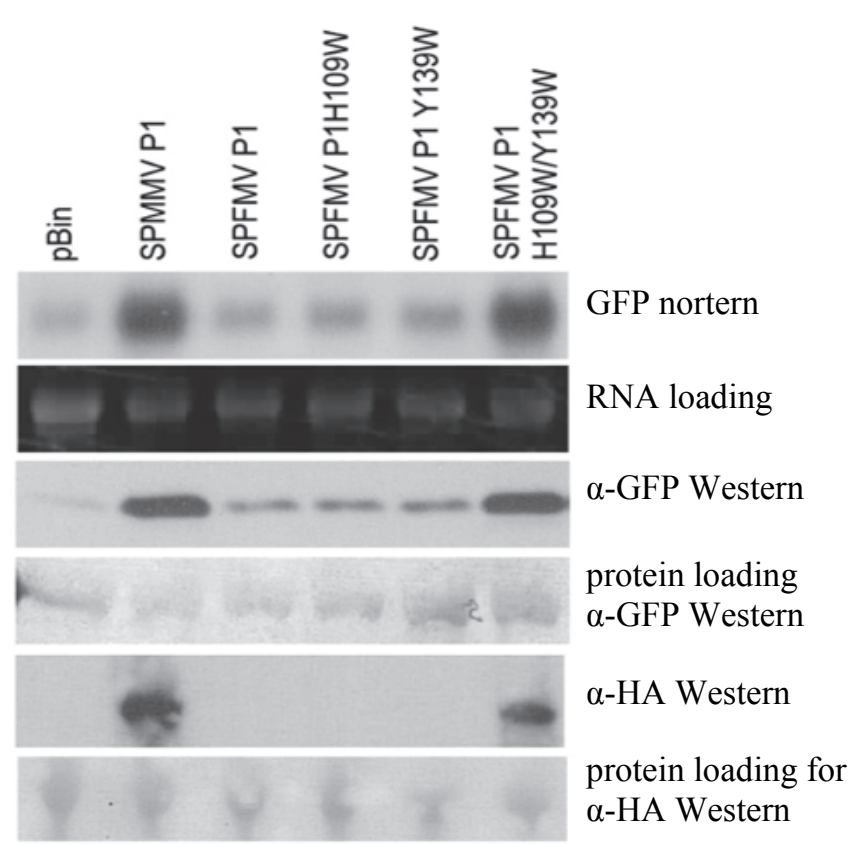

Figure 18. GFP expression analysis of the 35S-GFP infiltration test of SPFMV P1 mutants Top panel shows Northern analysis of GFP expression. The second panel shows RNA loading control. Third panel shows immunological detection of GFP protein. Panel four shows Ponceau staining used as loading control. Panel five the immunological detection of HA tagged SPFMV proteins. Last panel shows immunological detection of HA protein.

Wild type SPFMV P1 bearing one WG/GW domain did not have silencing suppressor activity. Our results showed that the SPFMV P1 mutants bearing two WG/GW domains (H109W and Y139W) also failed to show silencing suppressor activity. However, the SPFMV P1 double mutant H109W/Y139W having three WG/GW domains showed as strong silencing suppressor activity as SPMMV P1 did in our assay. Therefore we can conclude that partial restoration of the possible Argonaute binding domains of SPFMV P1 was not sufficient, but restoration of all possible Argonaute binding domains of SPFMV P1 resulting three in total, did result in RNA silencing suppressor activity of the protein. Here after we named the SPFMV P1 H109W/Y139W double as gain of function mutant.

\subsection{SPFMV P1 gain of function mutant is an AGO binging protein.}

The SPMMV P1 protein was shown to be an RNA silencing suppressor. Moreover, it was the first viral RNA silencing suppressor, which binds AGO via its WG/GW domains [66]. We showed that restoration of the WG/GW domain of the SPFMV P1 protein resulted in 
strong RNA silencing suppressor activity. To test AGO binding capacity, the HA-tagged WT and mutant forms of SPFMV P1 were used for co-infiltration with $6 \times$ mycAGO1 [63] and a 35S-GFP inverted repeat. To avoid the effect of RNA silencing, the GFP16c/RDR6i $N$. benthamiana line was used in this experiment, which does not have silencing against (even transiently expressed) transgenes [80].Western and Northern analyses of inputs and eluates of immunoprecipitations of the HA-tagged WT and mutant SPFMV and SPMMV P1 proteins were carried out. Using RNA silencing mutant $N$. benthamiana line GFP16c/RDR6i, HAtagged SPFMV P1 proteins having no silencing suppressor activity could be detected by Western blotting. Small RNA-loaded AGO1 binding ability was detected in the SPFMV H109W/ Y139W mutant and WT SPMMV P1 proteins but not in the SPFMV WT or H109W or Y139W mutant P1 protein (Figure 19.), thus indicating that silencing suppressor activity strongly correlated with the capability of AGO1 binding. Any of the two WG/GW motifs was sufficient for silencing of suppressor activity and AGO1 binding in the case of SPMMV P1 [66]. However, three $\mathrm{WG} / \mathrm{GW}$ motifs were absolutely required for SPFMV P1 to gain silencing suppressor activity.

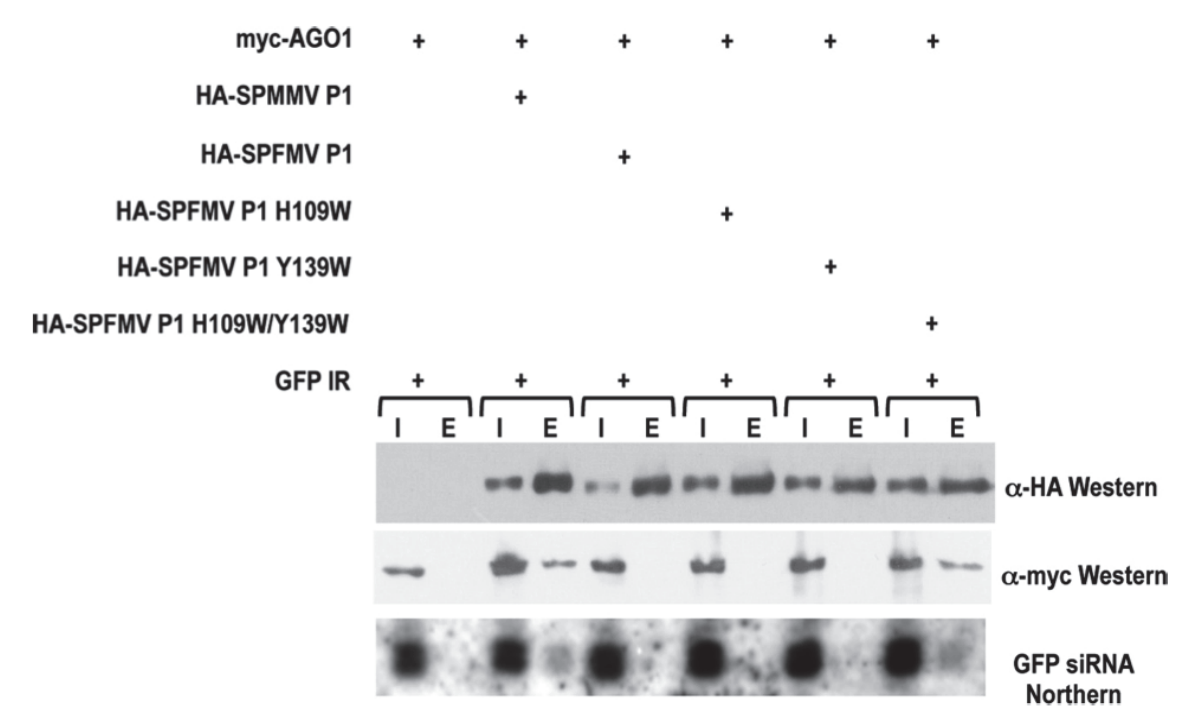

Figure 19. SPFMV P1 H109W/ Y139W bind AGO1 Immunoprecipitation was carried out from extracts of infiltrated leaves using anti-HA antibody. Top panel shows immunological detection of HA-tagged SPFMV proteins. Middle panel reveals detection of my-tagged proteins. Northern blotting shows the presence of GFP derived siRNAs at the lower panel. I and $\mathrm{E}$ stand for inputs and eluates. 


\subsection{Mechanistic studies of the SPFMV P1 gain of function mutant}

SPMMV P1 was the first RNA silencing suppressor that inhibits active RISC complexes [66]. Our studies showed that the SPFMV P1 reveals a notable similarity to the SPMMV P1. Moreover, the SPFMV P1 gain of function mutant has RNA silencing suppressor activity. Since there is a remarkable similarity between SPMMV P1 and SPFMV P1 gain of function mutant proteins, we hypothesized that SPFMV P1 gain of function mutant has a similar working mechanism. To evaluate this, we used the recently established method, which was developed to determine if the RNA silencing suppressor of interest inhibits RISC assembly or active RISC [66] [61].

Therefore, we agroinfiltrated Agrobacteria strains harboring SPFMV mutants H109W, Y139W and H109W/Y139W (gain of function mutant) with GFP-171.1 into fully developed $N$. benthamiana leaves. We used SPFMV P1 WT as a negative and SPMMV P1 as a positive control. After 36-48 hours visual inspection under UV light showed no GFP fluorescence in patches infiltrated with negative control. As it was shown previously, SPMMV P1 inhibited miR-171 driven RNA silencing in fully developed leaves [66]. Consistently with the standard agroinfiltration assay, SPFMV P1 mutants H109W, Y139W did not inhibit active RISC in this assay. Interestingly, The SPFMV P1 gain of function mutant inhibited active RISC as strongly as the prototype WG/GW domain RNA silencing suppressor SPMMV P1 (Figure 20.).

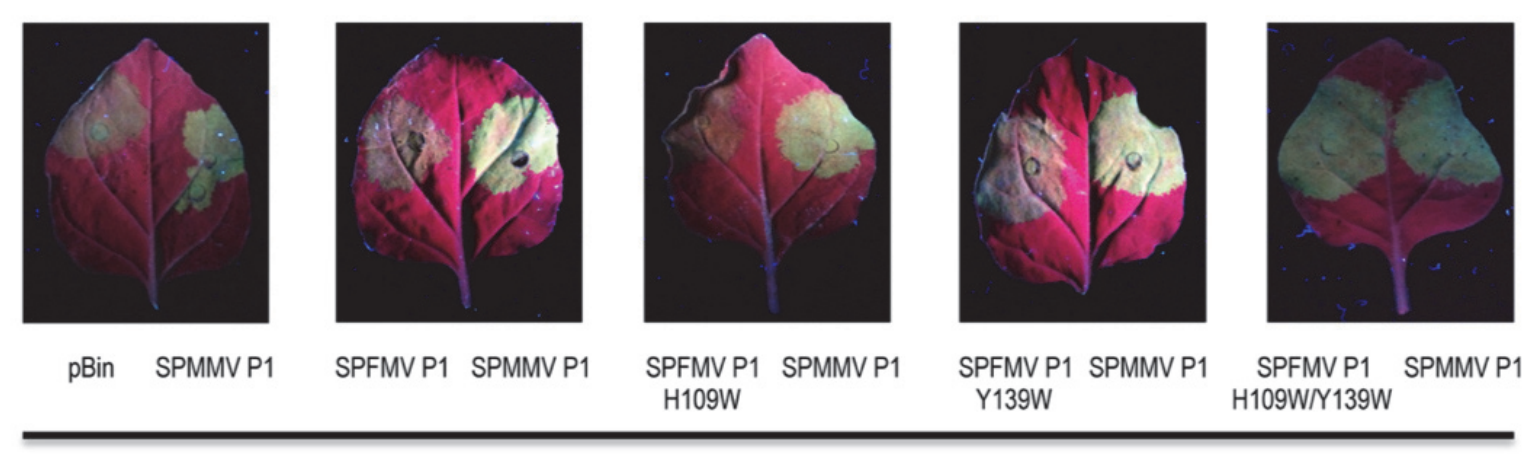

GFP-171.1

Figure 20. The double SPFMV P1 mutant inhibits active RISC The right side of each leave was infiltrated with the positive control (SPMMV P1). P1 constructs were co-infiltrated with GFP-171.1. The GFP fluorescence of the mutant of the interest was pared to SPMMV P1. Bright green fluorescence indicates silencing suppressor activity. 


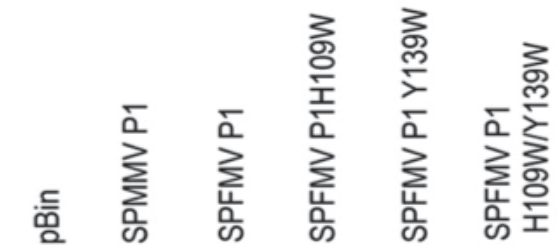

GFP Northern

RNA loading

$\alpha$-GFP Western

$\alpha$-HA Western

protein loading
Figure 21. GFP expression analysis of the GFP-171.1 infiltration test of SPFMV P1 mutants Top panel shows Northern analysis of GFP expression. The second panel is shows RNA loading control. Third panel shows immunological detection of GFP protein. Panel four the immunological detection of HA tagged SPFMV proteins Panel five shows Ponceau staining used as loading control.

The result of the GFP expression analysis was consistent with the result of the visual inspection. SPFMV P1 WT, the H109W and Y139W mutants did not support suppression of miR-171 loaded active RISC complexes. However, SPFMV P1 gain of function mutant and the SPMMV P1 inhibited active RISC, as shown by elevated GFP mRNA and protein levels compared to the negative control (Figure 21.).

Thus, we concluded that the SPFMV P1 gain of function mutant could have the same working mechanism than the SPMMV P1 RNA silencing suppressor. 


\section{Discussion}

During the course of our work, we characterized three proteins. The $16 \mathrm{~K}$ protein of TRV is an AGO binding RNA silencing suppressor, while the P1 protein of SPFMV P1 did not show any silencing suppressor activity. In the case of SPMMV P1, we found the shortest truncated mutant that still has RNA silencing suppressor activity. Finally, the great similarity between the SPFMV and SPMMV P1 proteins lead us to restore the AGO binding platform of the SPFMV protein that made the mutant protein have RNA silencing suppressor activity.

\subsection{Understanding the link between physiology and the working mechanism of the $16 \mathrm{~K}$ silencing suppressor of TRV}

TRV, the type member of the Tobravirus group, has a bipartite genome consisting of single stranded, positive sense RNAs. RNA 1 and RNA 2 of TRV can be separately encapsidated. As a consequence of the TRV genomic organization, RNA 1 can replicate and spread in plants in the absence of RNA 2 [81].

There is an accumulating knowledge about the $16 \mathrm{~K}$ silencing suppressor of TRV. Accumulation of TRV greatly reduced in the absence of the $16 \mathrm{~K}$ protein in N. benthamiana, which was the first indication of TRV having a silencing suppressor. Moreover functional replacement of TRV $16 \mathrm{~K}$ protein with the Cucumber mosaic virus $2 \mathrm{~b}$ gene, the Soil-borne wheat mosaic virus $19 \mathrm{~K}$ gene, or the Barley stripe mosaic virus gamma gene indicated that these proteins may have similar function [82]. It was also shown that TRV 16K allowed TRV to enter meristems and to invade the reproductive organs [83]. In another Tobravirus, pea early browning virus, the orthologue of the $16 \mathrm{~K}$ protein, mediates seed transmission [84]. TRV 16K found to be a weak suppressor of RNA silencing and that might explain why TRV enters the meristem transiently. If the suppressor activity were strong, the virus would accumulate to high levels in the meristematic cells and there would be severe damage to the infected plant [83], which would not be beneficial for either the host or the virus. Another study compared the steady state level of different miRNAs between mock and TRV infected Arabidopsis plants. They found that TRV infection caused a minor change in miRNA accumulation. Consistent with this finding, TRV-infected Arabidopsis plants did not show 
developmental abnormalities [83]. Moreover, TRV16K was found to be a relatively weak suppressor that effectively suppresses RNA silencing in the presence of low levels of dsRNA inducer. As dsRNA inducer accumulated, the suppressing activity of TRV-16K was fading away. TRV-16K notably reduced the accumulation of RNA silencing-associated siRNAs in the infiltrated tissue. At low levels of dsRNA inducer, TRV 16K was able to cause a remarkable reduction of silencing-associated siRNAs in the infiltrated leaf, whereas the reduction in siRNA levels was far less evident as dsRNA concentrations increased. Therefore, it was suggested that the suppressor activity of TRV $16 \mathrm{~K}$ was strongly linked to the reduced accumulation of siRNAs in the infiltrated patches [83] indicating that $16 \mathrm{~K}$ might inhibit the initiation step of RNA silencing.

Initiation of RNA silencing involves small RNA processing from dsRNA replicative forms or fold-backs of the genomic RNA. SiRNAs enter the AGO protein in a double stranded form. During formation of active RISC complexes ds siRNA became single stranded [85]. An amplification step of the silencing signal is strongly linked to RDR6 dependent spreading of RNA targeting, also known as transitivity, which involves generation of secondary siRNAs [45] [2] [19]. It was also previously shown that TRV $16 \mathrm{~K}$ also prevented partially cell-to-cell movement and systemic propagation of silencing but not transitive amplification of RNA silencing [72] indicating that $16 \mathrm{~K}$ is probably not targeting the RDR6 dependent signal amplification step.

Thus, TRV 16K inhibited the initiation step of RNA silencing by reducing the silencing associated siRNAs [83]. However, our collaborators found that $16 \mathrm{~K}$ bound AGO1, AGO2 and AGO4 of $A$. thaliana. This result raised the question that if $16 \mathrm{~K}$ inhibit the execution step of RISC (preassembled). Consistent with the result of Martin-Hernandez et al. (2008) [83], we found that 16K differed from P1 of SPMMV. In other words, 16K could not inhibit preassembled miRNA and siRNA RISC complexes, but at least one step of initiation of silencing, which involves AGO binding.

Some AGO binding silencing suppressors are inhibiting RISC assembly. For example, the P0 protein of Poleoviruses binds AGO1 and drives the degradation of the small RNA unloaded AGO 1 proteins [64] via the autophagy pathway [86]. Moreover, the p25 protein of the Potato virus $X$ targets and initiates small RNA unloaded AGO degradation through the proteasome [65]. At the moment we do not know how $16 \mathrm{~K}$ inhibits the initiation step of RNA 
silencing, but we believe that the working mechanism does not involve AGO degradation. However, we do know that the cysteine rich region of $16 \mathrm{~K}$ is involved in silencing suppressor activity, but not in AGO binding (Dr. César Llave, personal communication).

\subsection{The minimal silencing suppressor domain of the SPMMV P1}

The prototype RNA silencing suppressor inhibiting preassembled RISC is the SPMMV P1 protein, which consists of 759 amino acids. As it was shown before, this big protein in size contains the RNA silencing suppressor domain at the N-terminal part [66] and a protease domain conserved in the Potivirideae family [75]. Shorter versions of P1 were found in unrelated experiments implicated the functionality of these proteins. Thus, we narrowed the silencing suppressor domain to the N-terminal 210 amino acids of P1. This truncated protein has full silencing suppressor activity, compared to longer truncated mutants.

It is not surprising that a small part of a viral protein has a well-defined function. Virus genomes are limited in size, therefore, viruses have to have multifunctional proteins to be able to cope with the host. The recently found Nora virus of Drosophila melanogaster has the VP1 protein with host-specific RNA silencing suppressor activity. However, this suppressor domain is about $15 \mathrm{kDa} \mathrm{C}$-terminal part of the cca. $55 \mathrm{kDa}$ protein [87].

The small silencing suppressor domain is not only of biological interest, but it also has practical benefits. The small protein coding region is easier to work with. This allowed the Lakatos group to handle P1 simpler. Using this 210 amino acid version of P1 several mutants have been made, which allowed us to find that the zinc finger domain surrounding the GW/WG domain at position 101 on the protein plays a crucial role in silencing suppressor activity. Moreover, further truncated mutant were made that locates the silencing suppressor domain to the 26-193 amino acids on P1 protein. This protein does not contain intrinsically unstructured/disordered region and that is beneficial for example for crystallography approach. 
Unfortunately, no functional studies were performed with plant WG/GW protein are playing a crucial role in the transcriptional and miRNA driven RNA silencing. Two forms of RNA Polymerase IV (PolIVa/PolIVb) and the SPT5 (Suppressor of Ty insertion 5) RNA polymerase (RNAP) elongation factor family protein have been implicated in RNA-directed DNA methylation (RdDM) in Arabidopsis [41] [92]. Both proteins have a long region containing $>20 \mathrm{WG} / \mathrm{GW}$ motifs, which are involved in AGO4 interaction.

The SUO protein was also described as a possible $\mathrm{WG} / \mathrm{GW}$ motif protein. It plays an essential role in miRNA driven RNA silencing in $A$. thaliana. In contrast to the AGO4 binding WG/GW domain proteins, SUO contains only $2 \mathrm{WG} / \mathrm{GW}$ motifs [93]. Unfortunately, no biochemical evidence was shown about AGO binding yet.

The second group of $\mathrm{WG} / \mathrm{GW}$ proteins consists of the plant viral RNA silencing suppressors. The prototype WG/GW motif silencing suppressor is the P1 protein of SPMMV. Although P1 possesses three WG/GW motifs, two of them are required for full RNA silencing suppressor activity [66]. As we showed, the $\mathrm{WG} / \mathrm{GW}$ motifs are located the very $\mathrm{N}$-terminal part of the protein (this work), which consists of 210 amino acids. However, this protein was further truncated, thus the minimal silencing suppressor domain of P1 spans from the 26-193 amino acid. This portion of P1 contains 2 WG/GW motifs. As discussed earlier, two WG/GW domains are required for the human GW182 for full activity [91]. In a separate line of experiments other members of the Lakatos group found a zinc-finger fold in the SPMMV P1 protein spanning from 88-106 amino acid on the full-length protein. It was found that zincfinger fold was absolutely required for the activity, but not for AGO binding. Therefore, we can hypothesize that the $\mathrm{WG} / \mathrm{GW}$ motifs required for AGO binding and the zinc-finger fold is responsible for silencing suppression (Lakatos L, unpublished).

The SPFMV P1 protein contains only one WG/GW domain, which is located at the very N-terminal of the protein (W25). Our results showed that this protein has no silencing suppressor activity. Thus based on earlier results, we decided to reconstitute the remaining two WG/GW domains. In contrast to SPMMV P1, SPFMV P1 did not show any silencing suppressor activity when the $2^{\text {nd }}$ or the $3^{\text {rd }} \mathrm{WG} / \mathrm{GW}$ domain was reconstituted separately, but it did have suppressor activity when both of the "missing" WG/GW domains were restored by site directed mutagenesis. At the moment we could not provide a precise explanation for this. 


\subsection{Functional studies of the WG/GW domains}

From the functional point of view there are two different types of $\mathrm{WG} / \mathrm{GW}$ proteins:

$\mathrm{i}$; WG/GW proteins that have positive role in RNA silencing,

ii; WG/GW protein inhibiting RNA silencing.

Both types are Agronaute binding proteins. GW182, the prototype WG/GW protein, is absolutely required for miRNA driven RNA silencing [88]. It was also shown that the Cterminal half of GW182 contains multiply WG/GW domains that are required for translational repression [89]. The amino acids in the PIWI domain of Argonaute protein mediating the GW182-AGO interactions are the same that are required for binding of the first nucleotide of the miRNA [90]. Thus, mutating these amino acids is abolishing both small RNA and GW182 binding. A more detailed study revealed that several WG/GW domains of GW182 are able to interact AGO2 with different affinity. However, mutation of one Trp (W623) residue greatly reduced the affinity of the full length GW182 to AGO2. Moreover, they found that the AGO hook of GW182 is intrinsically unstructured and at least 10 amino acid distance is required for efficient AGO binding. Based on their results a model was built, which suggests that the N-terminal W (623) binds first to AGO2, because W623 has been shown to offer a stronger interaction with AGO2. Then the second Trp (W634) would still be flexible. In a last step, the second Trp binds to the other pocket, fixing the peptide in its orientation and resulting in full affinity [91] (Figure 22.).

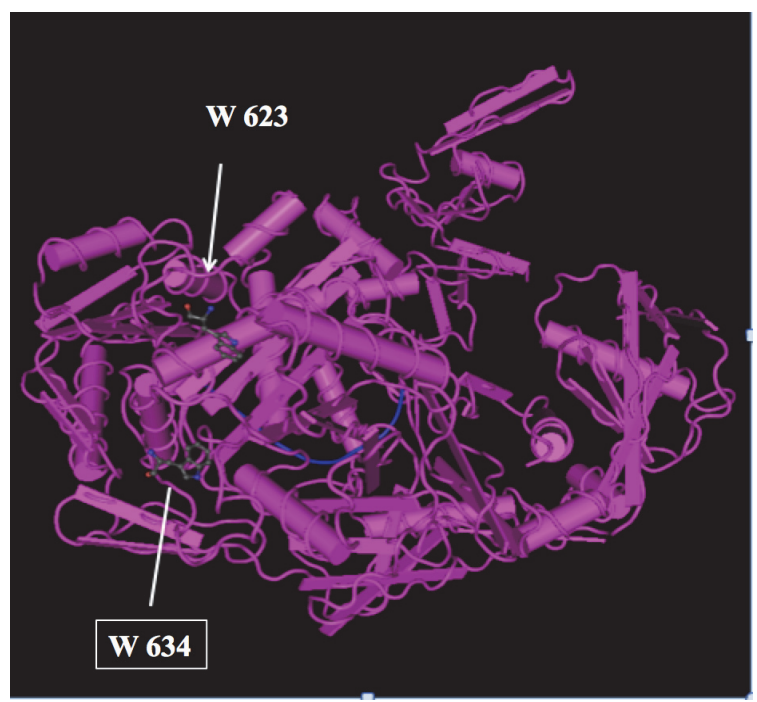

Figure 22. Graphical representation of the $\mathrm{W}$ binding regions on the human AGO2 structure The probable order of W binding pockets is described in the text. 
One possible explanation could be that in the case of SPFMV, all the WG/GW domains are required for proper folding of the protein.

\subsection{Possible working mechanism for SPFMV P1 gain of function mutant}

From the point of working mechanism, viral RNA silencing suppressors can be divided into two groups. In the first group there are suppressors, which are inhibiting RISC assembly, even by hampering siRNA processing, or siRNA sequestration. SiRNA unloaded AGO targeting is also an efficient way to inhibit RISC assembly [56]. In the second group of protein are inhibiting preassembled RISC [56]. The prototype preassembled RISC inhibiting suppressor is the P1 of SPMMV [66]. SPMMV P1 was shown to inhibit si- and miRNA driven preassembled RISC complexes. As we showed the SPFMV P1 gain of function mutant was also able to inhibit si- and miRNA driven preassembled RISC complexes. Thus, we concluded that both proteins might have the same working mechanism.

The recent model for SPMMV P1 suggested that in SPMMV infected cells, both existing and de novo assembled RISC complexes, including miRNA- and viral siRNA-loaded RISC complexes, should be considered as potential targets for P1. Thus, SPMMV P1 is not able to distinguish between miRNA and siRNA loaded RISC complexes. At the beginning of the infection, the concentration of existing active RISC might be much greater than that of the de novo viral siRNA-loaded active RISC, and this would lead to the sequestration of $\mathrm{P} 1$ mainly by existing preassembled RISC complexes. Consequently, one can hypothesize that the newly formed viral siRNA-loaded RISC complexes could escape from suppression, resulting in low SPMMV titer, mild transient symptoms, and recovery of the plant [66].

\subsection{Sequence specific versus sequence non-specific silencing suppressors}

Sequence specificity can be interpreted in several ways. For example, the coat protein of the Turnip crinkle virus has a dsRNA binding activity, by which it inhibits siRNA processing from replication intermediers [57]. This activity requires non-sequence specific dsRNA binding to work. Moreover the p19 of CymRSV, HC-Pro of TEV, 2b of CMV and other small RNA binding RNA silencing suppressors are sequestering small RNAs inhibiting RISC assembly with their non-specific small RNA binding activity. To do this, they recognize 
different chemical features on small RNAs. P19 of CymRSV binds the 5' end phosphate residue of the ds small RNA and measures its size as a molecular caliper [59]. HC-Pro preferentially binds $21 \mathrm{nt}$ ds small RNAs at their 3' end overhangs [61]. TAV $2 \mathrm{~b}$ recognize simultaneously two alpha-helical turns of A-form RNA duplex [62]. Finally, the RNA silencing suppressor SPMMV P1, which inhibits preassembled RISC complexes can not distinguish between miRNA and small RNA loaded RISC complexes indicating the lack of sequence specificity [66]. Since we proposed that SPFMV P1 gain of function mutant might work in a similar way than SPMMV P1, we believe sequence specificity is not involved in its working mechanism either. Thus, we can conclude that plant viral silencing suppressors do not work in a sequence specific way.

In contrast, Human cytomegalovirus (hCMV) is expressing a non-coding RNA, which shows a remarkable homology to the mature miR-17 and miR-20a encoded within the host miR-17-92 cluster. By a yet unidentified mechanism, but based on sequence specificity, the non-coding RNA UL144-145 reduces the mature miR-17 concentration in infected cells, thus allowing higher CMV titer [94]. Human miR-17 might be involved in promoting apoptosis, therefore, reducing the level of a pro-apoptotic miRNA could be beneficial for the pathogen. 


\section{Summary}

RNA silencing is a sequece specific RNA degradation mechanism that exists in almost all eukaryots. Among the severeal functions of RNA silencing, it senses and degrades molecular envaders, such as viruses. Viruses evolved silencing suppressors to overcome the effect of RNA silencing.

During the course of our work, we characterized three proteins. First was the $16 \mathrm{~K}$ protein of Tobacco rattle virus (TRV). In two assays we demonstrated that the AGO binding $16 \mathrm{~K}$ protein of TRV could not inhibit the activity of preassembled RISC complexes.

Previous studies demonstrated that the $\mathrm{P} 1$ protein of Sweet potato mild mottle virus (SPMMV) inhibits the active RNA induced silencing complex (RISC) by binding Argonaute, the catalytic component of RISC, via its three glicine-tryptophane (GW/WG) motifs.

In this studies we demonstrated, the minimal SPMMV P1 domain must contained every three GW/WG motifs to the silencing function.

We isolated the cDNA for the P1 protein of the Sweet potato feathery mottle virus (SPFMV). Sequence analysis showed that SPFMV P1 is highly homologous to the SPMMV $\mathrm{P} 1$, mostly in the region, where the GW/WG motifs are located in the SPMMV P1. However, SPFMV P1 contained only one GW/WG motif. Our functional studies showed that SPFMV P1 did not have any silencing suppressor activity. Interestingly, remodeling the AGO binding domain of SPFMV P1 by inserting two tryptophanes by in vitro mutagenesis resulted in gaining silencing suppressor activity and Argonaute binding. To our knowledge, this is the first instance of turning a viral protein of unknown function into a functional RNA silencing suppressor. 


\section{Acknowledgments}

I am very grateful to anybody, who helped me during the write of my thesis.

First of all, I would like to give special thank to my supervisor, Dr. Lóránt Lakatos, for the opportunity in the exciting field of RNA silencing.

I would like to thank Prof. Dr. Kemény Lajos, the head of Department of Dermatology and Allergology, University of Szeged, who allowed for my Ph.D. research at the institute.

I am grateful for the friendship of many colleagues during my time in Bay Zoltan Institute (Szeged) for their kind help. I thank Dr. Máté Manczinger, who also contributed to this work.

I would is especially like to thank my parents and friend for their support and encouragement.

This study was supported by the Hungarian Research Fund (OTKA) grants (NN 107787 and NN11024) to LL. KL was found by the European Union and co-financed by the European Social Fund (grant agreement no TÁMOP-4.2.2.A-11/1/KONV-2012-0035 and TÁMOP 4.2.4.A-2013/2-A2-SZJÖ-TOK-13). 


\section{Magyar nyelvü összefoglaló}

Az RNS silencing egy evolúciósan konzervált, specifikus RNS degradációs mechanizmus, amely szinte az összes eukarióta szervezetben müködik. Elöször növényekbe írták le, mint vírusok és transzgének elleni védekező mechanizmust, amely mára gombák, növények és állatok egyik legaktívabban kutatott területévé vált.

Az RNS silencing egy két lépéses, az mRNS-ek enzimatikus lebontásával járó folyamat. Az első, inicializáló lépés során a hosszú, duplaszálú (ds) RNS-ből endonukleáris mikro- (mi-) vagy kis interferáló (si-) RNS-ek képződnek. Ezek a kis, 21-26 bp nagyságú RNS-ek közös jellemzője a vágás során létrejövő 2 nukleotidnyi 3' túlnyúló vég és az 5' vég, melyet az RNáz-III-típusú enzimek, a dicerek alakítanak ki.

A második, effektor szakaszban az egyszálú si- és miRNS-ek egy ribonukleotid komplexhez, az RNS indukálta silencing komplexhez (RISC-hez) kapcsolódnak. A RISC enzimatikusan aktív központi molekulája az Argonauta (AGO) család tagjai, melyek a RISCben duplaszáló kis RNS-ekké párosodott RNS-eket több helyen elhasítják. Kis RNSsek szeparációja után pedig létrejön az aktív RISC, amely a vírusspecifikus siRNS-sek miatt specifikusan tudja gátolni a vírus RNS kifejeződését.

Az siRNS mediálta útvonal az egyik legfontosabb RNS silencing útvonal a növényi virológiában. Az antivirális silencing a citoplazmában játszódik le és a növényi vírusok dsRNS replikációját valamint a magasan struktúrált virális ssRNS iniciációját eredményezi, melynek végeredménye a citoplazmatikusan replikálódó vírusok vagy dsRNS, melyet a növényi RNS függő RNS polimeráz (RDR) hoz létre (RDR1 vagy RDR6). Növényekben az RDR6 által irányított folyamat a tranzitivitás, mely mindkét 5' végben előfordul és 3' vég direkt vágását indítja el az elsődleges siRNS által. Az újonnan szintetizált dsRNS szekvenciáját a DCL4 ismeri fel, mely 21nt hosszúságú másodlagos siRNS-t hoz létre, ezáltal gyorsítva a silencinget.

Argonauta (AGO) fehérjék központi szerepet játszanak különböző RNS silencing útvonalakban. A. thalianaba 10 különböző Argonauta fehérjét írtak le. Az AGO család alaptagjait Arabidopsis mutánsokban fedezték fel, mint pleiotróp fejlődési hibákat. Ezeket a mutánsokat argonaute1 (AGO1)-nek nevezték el. Az AGO1 mutánsoknál a transzgenikus silencing károsodását írták le, mely által a növényi vírusokkal szemben hiperszenzitívnak 
bizonyultak. Ezen kívül az AGO1 fontos szerepet játszik a miRNA regulálta fejlődési folyamatokban. Megemlítendő, hogy az AGO1 negatívan képes regulálni a miR-168 indukálását, ezáltal biztosítva a miRNS regulációjához szükséges egyensúlyt növényekben.

A növényi vírusok igen hatékony kórokozók, mivel képesek fertőzést okozni és behatolni a növénybe. Az a tény, hogy a legtöbb vírus RNS silencing szupresszorokat alakított ki hangsúlyozza az RNS silencing antivirális jellegét, valamint feltárja a kórokozók elleni védekező stratégiákat. A vírusok gyakran okoznak súlyos tüneteket, ami arra utal, hogy a kórokozók hatékonyan képesek zavarni a különböző RNS silencing utakat a gazdaszervezetben. Több RNS silencing szupresszort azonosítottak már viszont virális RNSek gátlásának felismerése és feldarabolása, mint silencing szupresszor stratégia csak pár növényi vírus esetében ismert.

SiRNS-ek megkötésével a RISC összeszerelödése megelőzhetö. A Tombusvírus p19 fehérjéi nagy affinitással kötődnek a 21 nukleotid hosszú siRNS-ekhez. Tobacco etch virus HC-Pro, Tobamovírus P122 és Tomato aspermy cucumovírus $2 \mathrm{~b}$ protein mind képes megakadályozni a RISC összeszerelődését azáltal, hogy megakadályozza az si/miRNS-ek bekötődését.

Ezidáig egyetlen RNS silencing szupresszort azonosítottak, amely képes gátolni az aktív RISC komplex kialakulását. Az édesburgonya enyhe levélfoltosságát okozó vírus P1 fehérjéje, a Sweet poteto mild mottle vírus (SPMMV P1) AGO1-hez kötődik a WG/GW domének segítségével, ezáltal képes a RISC aktivitását gátolni egy ma még ismeretlen mechanizmus során.

Tobacco rattle vírus (TRV), a tobravírus család tagja, amely pozitív, egyszálú RNSből álló kétrészes genomja van. A nagyobb genomi RNS, az RNS1 négy nyitott leolvasási keretet (ORF) tartalmaz. Az első két ORF által kódolt 134K és 194K molekulatömegü fehérjék , melyek "átolvasás" utáni transzlációjának terméke egy 134K gén. A két termék közvetlenül a vírus genomi RNS-éből expresszálódik. A harmadik ORF egy 29K fehérjét kódol, amely sejtről-sejtre történő mozgásban játszik központi szerepet. Végül, a 3' végen található negyedik ORF egy ciszteinben gazdag 16K fehérjét kódol, amely az RNS silencing szupresszor funkciót látja el. A $29 \mathrm{~K}$ és a $16 \mathrm{~K}$ fehérjék szubgenomi RNS-ből transzlálódnak. A genomi RNS2 tartalmazza a köpenyfehérje génjét és a génterméke szabályozza a vektor átvihetőségét. 
Több mint 40 növényi virális RNS silencing szupresszort azonosítottak napjainkig, mely közül csak néhánynak sikerült eddig leírni pontos müködési mechanizmusát. Annak érdekében, hogy pontosabban megérthessük az AGO kötő silencing szupresszorok müködését a következő célokat határoztuk meg:

1. Tobacco rattle vírus $16 \mathrm{k}$ silencing szupresszorának jellemzése

2. Sweet poteto mild mottle virus $\mathrm{P} 1$ fehérje silencing szupresszor aktivitással rendelkező minimális doménhosszának meghatározása

3. Sweet poteto feathery mottle vírus P1 fehérje Ago-kötő régiójának újraszerkesztése

Vizsgálatainkat $N$. benthaimana növényen végeztük infiltrációs kísérletekkel. Eredményeinket UV lámpával megvilágított levelek vizuális vizsgálata mellett western és northern blottokkal is alátámasztottuk.

Tobacco rattle vírus (TRV) fertőzés az RNS silencing szoros ellenőrzése alatt áll, ami a magas TRV szintből következtethetö ki olyan növényekben, melyekben az RNS silencing komponenseket genetikailag inaktiválták. A $16 \mathrm{~K}$ a sejtről sejtre mozgásokat gátolja valamint a silencing terjedését gátolja, de az RDR-függő RNS silencinget nem.

Partnereink arra kértek bennünket, hogy támasszuk alá a 16K-val kapcsolatos eredményeiket. Azt találták, hogy a $16 \mathrm{~K}$ de novo megszüntette az aktív RISC müködését és ezéltal a vágási termékek kialakulását. Söt, 16K nem volt képes megkötni a szintetikus kis RNS-eket. Azt is bebizonyították, hogy a $16 \mathrm{~K}$ N-terminálisán található cisztein gazdag motívumok szükségesek a silencing szupresszor müködéshez.Vizsgálataink előzményeként megállapították, hogy a TRV 16k plazmid DNS-t 35S-GFP reporter gén mellett képes gátolni az aktív RISC felépülését, de maga a mechanizmus még nem lett leírva.

Cymbibium ringspot vírus 19 stop mutánsával fertőzött és kissé tünetes $N$. benthamiana levelekbe infiltráltuk a a TRV 16k plazmidját cym- illetve polv-GFP reportergének mellett. A cym19 stop hatására kialakul az aktív RISC, a cym-gfp konstrukciót tartalmazó plazmidot kifejező mRNS-t célzottan hasítja a RISC komplex, míg a polv-gfp független a cymringspot vírustól, így az nem hasad, negatív kontrollként használható a rendszerben. Pozitív kontrollként ismert silencing szupresszorokat használtunk. Az össz GFPfehérje mennyisége szignifikánsan kevesebb volt a GFP-Cym konstrukciót tartalmazó mintáknál, mint a GFP-PoLV esetében. Sőt, a GFP-specifikus RNS rövidebb volt a vártnál. 
Ahogy az várható volt, SPMMV P1 gátolta a virális siRNS bekötését a felépülö RISC-be, amelyet a megnövekedett fluoreszcencia jelzett az infiltrációs gyürüben, valamint Northern blotton a hasítási termékekből származó rövidebb GFP hiánya.

Ezután egy újabb in vivo rendszerbe vizsgáltuk a $16 \mathrm{~K}$ silencingre gyakorolt hatását. Vizsgálat alapja az, hogy a miR 171.1 hatására az aktív RISC komplexek teljesen képes kifejeződni $N$. benthamiana levelében. Ezáltal az RNS silencing szupresszor gátló hatásának hiánya az aktív RISC komplexre az mRNS degradációját eredményezi, és a GFP csökkent felhalmozódásával jár. Megfigyeléseink alapján elmondható, hogy a 16K+GFP171.1 konstrukció esetében jóval alacsonyabb, mint a pozitív kontroll esetében, de hasonló a negatív kontroll TEV Hc-Prohoz, vagyis a 16K nem képes gátolni a RISC komplex összeszerelődését.

A minimális doménhossz vizsgálatának meghatározására a teljes, 383 aminosav hosszú SPMMV P1-ből megfelelő primerek segítségével hoztuk létre az N-terminálisan 360, 330, 251 és 210 aminosav hosszú SPMMV P1-et. Az így elkészített DNS-eket pSanyi növényi vektorba klónoztuk, mely vektor N-terminálisa HA jelölt. A különböző domnénhosszúságú minták aktivitását először GFP 171.1 riportergén mellett vizsgáltuk. Mivel az SPMMV P1 $1_{1-383}$ egy korábban már jól jellemzett silencing szupresszor, így ezt alkalmaztuk pozitív kontrollként. UV fénnyel megvilágított leveleken a $\mathrm{P} 1_{1-210}$-es mutáns esetében csökkent aktivitását tapasztaltuk. Ezt az eredményt Western blottal is megerősítettük. Míg a többi mutáns erős, a pozitív kontrollal megegyező jelerősséget mutatott, addig a $\mathrm{P}_{1-210}$ esetében jóval alacsonyabb, a negatív kontrollal megegyező jelerőséget tapasztaltunk. Ezen eredmények alapján elmondható, hogy a $\mathrm{P} 1_{1-120}$-as mutáns tehát már nem működik silencing szupresszorként. A csökkentett doménhosszúságú, működő silencing szupresszorok nagyságát HA-ellenes ellenanyaggal mutattuk ki, ahol a csökkenő aminosavméret szépen kirajzolódik. P1 $1_{1-120}$ aminosavról nem expresszálódott megfelelő fehérje. Vizsgálataink során megállapítottuk, hogy az SPMMV P1 silencing szupresszor esetében akkor marad meg a funkció ha mindhárom $\mathrm{GW} / \mathrm{WG}$ motívum jelen van a rendszerben. A csonkított mutánsoknál csak az nem működött, ahol az utolsó, 3. ilyen motívumot is eltávolítottuk a rendszerből.

A Sweet poteto feathery mottle virus (SPFMV) P1 fehérjéjet nagyfokú homológiát mutatott in silico az SPMMV P1 fehérjével. A legfontosabb különbség az SPMMV P1 fehérjéhez képest, hogy nem tartalmaz csak 1 GW/WG motívumot a 25. pozícióban. Elözetes 
vizsgálatokkal meghatároztuk, hogy az SPFMV P1 eredeti formájában nem képes silecing szupresszorként funkcionálni. Miután az SPMMV P1 esetében meghatároztuk azt a minimális doménhosszúságot, ami a fehérje silencing szupresszor aktivitásához szükséges, és az SPFMV P1 esetében in silico meghatároztuk azokat a pozíciókat ahova a hiányzó két WG/GW motívumot, úgy be lehet tenni hogy müködő szupresszor legyen, irányított mutagenezissel megalkottuk a mutánsokat. Eredeti SPFMV P1-ben levő 25. pozíciójú GW/WG motívum mellé, a 109. illetve a 139. pozícióba tettük be a hiányzó WG/GW motívumokat létrehozva ezáltal a kettős mutánsokat, valamint az SPMMV P1-hez hasonlóan mindhárom WG/GW motívumot tartalmazó hármas mutánsokat. A mutánsok silencing szupresszor aktivitását először 35S-GFP riporter gén mellett vizsgáltuk. Ebbe a rendszerbe csak azt tudjuk megállapítani, hogy az adott mutáns mutat-e szupresszor aktivitást vagy sem. Pozitív kontrollként a teljes hosszúságú SPMMV P1-et alkalmaztuk, mellyel azonos erősségü jelet csak a H109W/Y139W hármas mutáns esetében kaptunk, a másik kettő funkcionális aktivitást nem mutatott. Megfigyeléseinket western és northern blot analízissel is alátámasztottuk.

Ko-immunprecipitációs kísérletek során myc-ago és SPFMV mutánsok interakcióját vizsgáltuk inverted repeat GFP mellett. Az AGO megjelent az SPMMVP1 és az SPFMVP1 H109W/Y139W mutáns eluátumában, tehát az interakció a kontrollhoz hasonlóan ténylegesen is létrejött, a hármas mutáns képes az AGO fehérjével tényleges, funkcionális kapcsolat kialakítására, míg a többi mutáns esetében ez nem volt tapasztalható.

Annak érdekében, hogy megtudhassuk milyen útvonalon gátolja az RNS silencing mechanizmusát 171.1GFP riporter gén mellett infiltráltuk a mutánsokat. Hipotézisünk alapján a működő mutáns az SPMMV P1hez hasonló mechanizmus alapján müködik,vagyis az aktív RISC felépülését gátolja így vizsgálati rendszerünkben ismét ezt használtuk pozitív kontrollnak. Vizuális megfigyeléseink alapján az SPFMV P1 hármas mutánsa hasonló mértékü jelintenzitás növekedést mutatott mint, az SPMMV P1, tehát ez a mutáns az aktív RISC felépülését gátolja, a többi mutánsnál ismételten nem tapasztaltunk változást. Ezen eredményeinket western és kis RNS northern blottal is megerősítettük. Ezzel ténylegesen is bebizonyosodott, hogy az SPFMV P1 H109W/Y139W hármas mutánsa ténylegesen működő, a silencinget aktívan gátló silencing szupresszor. 


\section{References}

1. Sontheimer, E.J., Assembly and function of RNA silencing complexes. Nat Rev Mol Cell Biol, 2005. 6(2): p. 127-38.

2. Ding, S.W. and O. Voinnet, Antiviral immunity directed by small RNAs. Cell, 2007. 130(3): p. 413-26.

3. Tomari, Y. and P.D. Zamore, Perspective: machines for RNAi. Genes Dev, 2005. 19(5): p. 517-29.

4. Napoli, C., C. Lemieux, and R. Jorgensen, Introduction of a Chimeric Chalcone Synthase Gene into Petunia Results in Reversible Co-Suppression of Homologous Genes in trans. Plant Cell, 1990. 2(4): p. 279-289.

5. van der Krol, A.R., et al., Inhibition of flower pigmentation by antisense CHS genes: promoter and minimal sequence requirements for the antisense effect. Plant Mol Biol, 1990. 14(4): p. 457-66.

6. Lindbo, J.A. and W.G. Dougherty, Untranslatable transcripts of the tobacco etch virus coat protein gene sequence can interfere with tobacco etch virus replication in transgenic plants and protoplasts. Virology, 1992. 189(2): p. 725-33.

7. Ratcliff, F.G., S.A. MacFarlane, and D.C. Baulcombe, Gene silencing without DNA. rna-mediated cross-protection between viruses. Plant Cell, 1999. 11(7): p. 1207-16.

8. Romano, N. and G. Macino, Quelling: transient inactivation of gene expression in Neurospora crassa by transformation with homologous sequences. Mol Microbiol, 1992. 6(22): p. 3343-53.

9. Fire, A., et al., Potent and specific genetic interference by double-stranded RNA in Caenorhabditis elegans. Nature, 1998. 391(6669): p. 806-11.

10. Hamilton, A.J. and D.C. Baulcombe, A species of small antisense RNA in posttranscriptional gene silencing in plants. Science, 1999. 286(5441): p. 950-2.

11. Lee, R.C., R.L. Feinbaum, and V. Ambros, The C. elegans heterochronic gene lin-4 encodes small RNAs with antisense complementarity to lin-14. Cell, 1993. 75(5): p. 843-54.

12. Bernstein, E., et al., Role for a bidentate ribonuclease in the initiation step of RNA interference. Nature, 2001. 409(6818): p. 363-6. 
13. Hutvagner, G., et al., A cellular function for the RNA-interference enzyme Dicer in the maturation of the let-7 small temporal RNA. Science, 2001. 293(5531): p. 834-8.

14. Bartel, D.P., MicroRNAs: genomics, biogenesis, mechanism, and function. Cell, 2004. 116(2): p. 281-97.

15. Dalmay, T., et al., Potato virus $X$ amplicons in arabidopsis mediate genetic and epigenetic gene silencing. Plant Cell, 2000. 12(3): p. 369-79.

16. Molnar, A., et al., Plant virus-derived small interfering RNAs originate predominantly from highly structured single-stranded viral RNAs. J Virol, 2005. 79(12): p. 7812-8.

17. Deleris, A., et al., Hierarchical action and inhibition of plant Dicer-like proteins in antiviral defense. Science, 2006. 313(5783): p. 68-71.

18. Silhavy, D., et al., A viral protein suppresses RNA silencing and binds silencinggenerated, 21- to 25-nucleotide double-stranded RNAs. EMBO J, 2002. 21(12): p. 3070-80.

19. Himber, C., et al., Transitivity-dependent and-independent cell-to-cell movement of RNA silencing. EMBO J, 2003. 22(17): p. 4523-33.

20. Melnyk, C.W., et al., Mobile 24 nt small RNAs direct transcriptional gene silencing in the root meristems of Arabidopsis thaliana. Curr Biol, 2011. 21(19): p. 1678-83.

21. Melnyk, C.W., A. Molnar, and D.C. Baulcombe, Intercellular and systemic movement of RNA silencing signals. EMBO J, 2011. 30(17): p. 3553-63.

22. Xie, Z., et al., Expression of Arabidopsis MIRNA genes. Plant Physiol, 2005. 138(4): p. $2145-54$.

23. Kim, V.N., MicroRNA biogenesis: coordinated cropping and dicing. Nat Rev Mol Cell Biol, 2005. 6(5): p. 376-85.

24. Park, W., et al., CARPEL FACTORY, a Dicer homolog, and HEN1, a novel protein, act in microRNA metabolism in Arabidopsis thaliana. Curr Biol, 2002. 12(17): p. 1484-95.

25. Li, J., et al., Methylation protects miRNAs and siRNAs from a 3'-end uridylation activity in Arabidopsis. Curr Biol, 2005. 15(16): p. 1501-7.

26. Park, M.Y., et al., Nuclear processing and export of microRNAs in Arabidopsis. Proc Natl Acad Sci U S A, 2005. 102(10): p. 3691-6. 
27. Baumberger, N. and D.C. Baulcombe, Arabidopsis ARGONAUTE1 is an RNA Slicer that selectively recruits microRNAs and short interfering RNAs. Proc Natl Acad Sci U S A, 2005. 102(33): p. 11928-33.

28. Vaucheret, H., A.C. Mallory, and D.P. Bartel, AGO1 homeostasis entails coexpression of MIR168 and AGO1 and preferential stabilization of miR168 by AGO1. Mol Cell, 2006. 22(1): p. 129-36.

29. Xie, Z., et al., Genetic and functional diversification of small RNA pathways in plants. PLoS Biol, 2004. 2(5): p. E104.

30. Allen, E., et al., microRNA-directed phasing during trans-acting siRNA biogenesis in plants. Cell, 2005. 121(2): p. 207-21.

31. Gasciolli, V., et al., Partially redundant functions of Arabidopsis DICER-like enzymes and a role for DCL4 in producing trans-acting siRNAs. Curr Biol, 2005. 15(16): p. 1494-500.

32. Borsani, O., et al., Endogenous siRNAs derived from a pair of natural cis-antisense transcripts regulate salt tolerance in Arabidopsis. Cell, 2005. 123(7): p. 1279-91.

33. Wang, X.J., T. Gaasterland, and N.H. Chua, Genome-wide prediction and identification of cis-natural antisense transcripts in Arabidopsis thaliana. Genome Biol, 2005. 6(4): p. R30.

34. Wassenegger, M., et al., RNA-directed de novo methylation of genomic sequences in plants. Cell, 1994. 76(3): p. 567-76.

35. Wassenegger, M., RNA-directed DNA methylation. Plant Mol Biol, 2000. 43(2-3): p. 203-20.

36. Cao, X. and S.E. Jacobsen, Role of the arabidopsis DRM methyltransferases in de novo DNA methylation and gene silencing. Curr Biol, 2002. 12(13): p. 1138-44.

37. Zilberman, D., et al., Role of Arabidopsis ARGONAUTE4 in RNA-directed DNA methylation triggered by inverted repeats. Curr Biol, 2004. 14(13): p. 1214-20.

38. Aufsatz, W., et al., The role of MET1 in RNA-directed de novo and maintenance methylation of CG dinucleotides. Plant Mol Biol, 2004. 54(6): p. 793-804.

39. Jackson, J.P., et al., Control of CpNpG DNA methylation by the KRYPTONITE histone H3 methyltransferase. Nature, 2002. 416(6880): p. 556-60. 
40. Chan, S.W., I.R. Henderson, and S.E. Jacobsen, Gardening the genome: DNA methylation in Arabidopsis thaliana. Nat Rev Genet, 2005. 6(5): p. 351-60.

41. El-Shami, M., et al., Reiterated $W G / G W$ motifs form functionally and evolutionarily conserved ARGONAUTE-binding platforms in RNAi-related components. Genes Dev, 2007. 21(20): p. 2539-44.

42. Wierzbicki, A.T., et al., Spatial and functional relationships among Pol V-associated loci, Pol IV-dependent siRNAs, and cytosine methylation in the Arabidopsis epigenome. Genes Dev, 2012. 26(16): p. 1825-36.

43. Wierzbicki, A.T., et al., RNA polymerase $V$ transcription guides ARGONAUTE4 to chromatin. Nat Genet, 2009. 41(5): p. 630-4.

44. Ream, T.S., et al., Subunit compositions of the RNA-silencing enzymes Pol IV and Pol $V$ reveal their origins as specialized forms of RNA polymerase II. Mol Cell, 2009. 33(2): p. 192-203.

45. Brodersen, P. and O. Voinnet, The diversity of RNA silencing pathways in plants. Trends Genet, 2006. 22(5): p. 268-80.

46. Moissiard, G. and O. Voinnet, RNA silencing of host transcripts by cauliflower mosaic virus requires coordinated action of the four Arabidopsis Dicer-like proteins. Proc Natl Acad Sci U S A, 2006. 103(51): p. 19593-8.

47. Song, J.J., et al., Crystal structure of Argonaute and its implications for RISC slicer activity. Science, 2004. 305(5689): p. 1434-7.

48. Elkayam, E., et al., The structure of human argonaute-2 in complex with miR-20a. Cell, 2012. 150(1): p. 100-10.

49. Liu, J., et al., Argonaute2 is the catalytic engine of mammalian RNAi. Science, 2004. 305(5689): p. 1437-41.

50. Rivas, F.V., et al., Purified Argonaute2 and an siRNA form recombinant human RISC. Nat Struct Mol Biol, 2005. 12(4): p. 340-9.

51. Bohmert, K., et al., AGO1 defines a novel locus of Arabidopsis controlling leaf development. EMBO J, 1998. 17(1): p. 170-80.

52. Morel, J.B., et al., Fertile hypomorphic ARGONAUTE (agol) mutants impaired in post-transcriptional gene silencing and virus resistance. Plant Cell, 2002. 14(3): p. 629-39. 
53. Vaucheret, H., et al., The action of ARGONAUTE1 in the miRNA pathway and its regulation by the miRNA pathway are crucial for plant development. Genes Dev, 2004. 18(10): p. 1187-97.

54. Carbonell, A., et al., Functional analysis of three Arabidopsis ARGONAUTES using slicer-defective mutants. Plant Cell, 2012. 24(9): p. 3613-29.

55. Eun, C., et al., AGO6 functions in RNA-mediated transcriptional gene silencing in shoot and root meristems in Arabidopsis thaliana. PLoS One, 2011. 6(10): p. e25730.

56. Burgyan, J. and Z. Havelda, Viral suppressors of RNA silencing. Trends Plant Sci, 2011. 16(5): p. 265-72.

57. Merai, Z., et al., Double-stranded RNA binding may be a general plant RNA viral strategy to suppress RNA silencing. J Virol, 2006. 80(12): p. 5747-56.

58. Glick, E., et al., Interaction with host SGS3 is required for suppression of RNA silencing by tomato yellow leaf curl virus V2 protein. Proc Natl Acad Sci U S A, 2008. 105(1): p. 157-61.

59. Vargason, J.M., et al., Size selective recognition of siRNA by an RNA silencing suppressor. Cell, 2003. 115(7): p. 799-811.

60. Csorba, T., et al., The p122 subunit of Tobacco Mosaic Virus replicase is a potent silencing suppressor and compromises both small interfering RNA- and microRNAmediated pathways. J Virol, 2007. 81(21): p. 11768-80.

61. Lakatos, L., et al., Small RNA binding is a common strategy to suppress RNA silencing by several viral suppressors. EMBO J, 2006. 25(12): p. 2768-80.

62. Chen, H.Y., et al., Structural basis for RNA-silencing suppression by Tomato aspermy virus protein 2b. EMBO Rep, 2008. 9(8): p. 754-60.

63. Zhang, X., et al., Cucumber mosaic virus-encoded $2 b$ suppressor inhibits Arabidopsis Argonaute1 cleavage activity to counter plant defense. Genes Dev, 2006. 20(23): p. 3255-68.

64. Csorba, T., et al., Polerovirus protein P0 prevents the assembly of small RNAcontaining RISC complexes and leads to degradation of ARGONAUTE1. Plant J, 2010. 62(3): p. 463-72. 
65. Chiu, M.H., et al., The silencing suppressor P25 of Potato virus $X$ interacts with Argonautel and mediates its degradation through the proteasome pathway. Mol Plant Pathol, 2010. 11(5): p. 641-9.

66. Giner, A., et al., Viral protein inhibits RISC activity by argonaute binding through conserved $W G / G W$ motifs. PLoS Pathog, 2010. 6(7): p. e1000996.

67. Ploeg, A.T., D.J. Robinson, and D.J. Brown, RNA-2 of tobacco rattle virus encodes the determinants of transmissibility by trichodorid vector nematodes. J Gen Virol, 1993. 74 ( Pt 7): p. 1463-6.

68. Wise, A.A., Z. Liu, and A.N. Binns, Three methods for the introduction of foreign DNA into Agrobacterium. Methods Mol Biol, 2006. 343: p. 43-53.

69. Feinberg, A.P. and B. Vogelstein, A technique for radiolabeling DNA restriction endonuclease fragments to high specific activity. Anal Biochem, 1983. 132(1): p. 613.

70. Stiekema, W.J., et al., Molecular cloning and analysis of four potato tuber mRNAs. Plant Mol Biol, 1988. 11(3): p. 255-69.

71. Donaire, L., et al., Structural and genetic requirements for the biogenesis of tobacco rattle virus-derived small interfering RNAs. J Virol, 2008. 82(11): p. 5167-77.

72. Martinez-Priego, L., et al., Silencing suppressor activity of the Tobacco rattle virusencoded 16-kDa protein and interference with endogenous small RNA-guided regulatory pathways. Virology, 2008. 376(2): p. 346-56.

73. Ghazala, W., et al., Functional characterization and subcellular localization of the $16 K$ cysteine-rich suppressor of gene silencing protein of tobacco rattle virus. $\mathrm{J}$ Gen Virol, 2008. 89(Pt 7): p. 1748-58.

74. Szittya, G., et al., Short defective interfering RNAs of tombusviruses are not targeted but trigger post-transcriptional gene silencing against their helper virus. Plant Cell, 2002. 14(2): p. 359-72.

75. Valli, A., J.J. Lopez-Moya, and J.A. Garcia, Recombination and gene duplication in the evolutionary diversification of P1 proteins in the family Potyviridae. J Gen Virol, 2007. 88(Pt 3): p. 1016-28. 
76. Parizotto, E.A., et al., In vivo investigation of the transcription, processing, endonucleolytic activity, and functional relevance of the spatial distribution of a plant miRNA. Genes Dev, 2004. 18(18): p. 2237-42.

77. Shiboleth, Y.M., et al., The conserved FRNK box in HC-Pro, a plant viral suppressor of gene silencing, is required for small RNA binding and mediates symptom development. J Virol, 2007. 81(23): p. 13135-48.

78. Kertesz, S., et al., Both introns and long 3'-UTRs operate as cis-acting elements to trigger nonsense-mediated decay in plants. Nucleic Acids Res, 2006. 34(21): p. 614757.

79. Vargason, J.M., C.J. Burch, and J.W. Wilson, Identification and RNA binding characterization of plant virus RNA silencing suppressor proteins. Methods, 2013. 64(1): p. 88-93.

80. Schwach, F., et al., An RNA-dependent RNA polymerase prevents meristem invasion by potato virus $X$ and is required for the activity but not the production of a systemic silencing signal. Plant Physiol, 2005. 138(4): p. 1842-52.

81. Hernandez, C., et al., Serial passage of tobacco rattle virus under different selection conditions results in deletion of structural and nonstructural genes in RNA 2. J Virol, 1996. 70(8): p. 4933-40.

82. Liu, H., et al., Functional replacement of the tobacco rattle virus cysteine-rich protein by pathogenicity proteins from unrelated plant viruses. Virology, 2002. 298(2): p. 232-9.

83. Martin-Hernandez, A.M. and D.C. Baulcombe, Tobacco rattle virus 16-kilodalton protein encodes a suppressor of RNA silencing that allows transient viral entry in meristems. J Virol, 2008. 82(8): p. 4064-71.

84. Wang, D., S.A. MacFarlane, and A.J. Maule, Viral determinants of pea early browning virus seed transmission in pea. Virology, 1997. 234(1): p. 112-7.

85. Meister, G. and T. Tuschl, Mechanisms of gene silencing by double-stranded RNA. Nature, 2004. 431(7006): p. 343-9.

86. Derrien, B., et al., Degradation of the antiviral component ARGONAUTE1 by the autophagy pathway. Proc Natl Acad Sci U S A, 2012. 109(39): p. 15942-6. 
87. van Mierlo, J.T., et al., Novel Drosophila viruses encode host-specific suppressors of RNAi. PLoS Pathog, 2014. 10(7): p. e1004256.

88. Eulalio, A., E. Huntzinger, and E. Izaurralde, GW182 interaction with Argonaute is essential for miRNA-mediated translational repression and $m R N A$ decay. Nat Struct Mol Biol, 2008. 15(4): p. 346-53.

89. Lian, S.L., et al., The C-terminal half of human Ago2 binds to multiple GW-rich regions of GW182 and requires GW182 to mediate silencing. RNA, 2009. 15(5): p. 804-13.

90. Till, S., et al., A conserved motif in Argonaute-interacting proteins mediates functional interactions through the Argonaute PIWI domain. Nat Struct Mol Biol, 2007. 14(10): p. 897-903.

91. Pfaff, J., et al., Structural features of Argonaute-GW182 protein interactions. Proc Natl Acad Sci U S A, 2013. 110(40): p. E3770-9.

92. Bies-Etheve, N., et al., RNA-directed DNA methylation requires an AGO4-interacting member of the SPT5 elongation factor family. EMBO Rep, 2009. 10(6): p. 649-54.

93. Yang, L., G. Wu, and R.S. Poethig, Mutations in the GW-repeat protein SUO reveal a developmental function for microRNA-mediated translational repression in Arabidopsis. Proc Natl Acad Sci U S A, 2012. 109(1): p. 315-20.

94. Lee, S., et al., Selective degradation of host MicroRNAs by an intergenic HCMV noncoding RNA accelerates virus production. Cell Host Microbe, 2013. 13(6): p. 67890. 
I. 


\section{Journal of \\ Switching on RNA Silencing Suppressor Activity by Restoring Argonaute Binding to a Viral Protein}

Virology

Edit Z. Szabó, Máté Manczinger, Anikó Göblös, Lajos

Kemény and Lóránt Lakatos

J. Virol. 2012, 86(15):8324. DOI: 10.1128/JVI.00627-12.

Published Ahead of Print 23 May 2012.

Updated information and services can be found at:

http://jvi.asm.org/content/86/15/8324

\section{These include:}

REFERENCES

This article cites 16 articles, 7 of which can be accessed free at: http://jvi.asm.org/content/86/15/8324\#ref-list-1

CONTENT ALERTS

Receive: RSS Feeds, eTOCs, free email alerts (when new articles cite this article), more» 


\title{
Switching on RNA Silencing Suppressor Activity by Restoring Argonaute Binding to a Viral Protein
}

\author{
Edit Z. Szabó, ${ }^{a}$ Máté Manczinger, ${ }^{a}$ Anikó Göblös, ${ }^{a}$ Lajos Kemény, ${ }^{a, b}$ and Lóránt Lakatos ${ }^{a}$ \\ Department of Dermatology and Allergology, University of Szeged, Szeged, Hungary, and Dermatological Research Group of the Hungarian Academy of Sciences and \\ the University of Szeged, Szeged, Hungary ${ }^{\mathrm{b}}$
}

\begin{abstract}
We found that Sweet potato feathery mottle virus (SPFMV) P1, a close homologue of Sweet potato mild mottle virus P1, did not have any silencing suppressor activity. Remodeling the Argonaute (AGO) binding domain of SPFMV P1 by the introduction of two additional WG/GW motifs converted it to a silencing suppressor with AGO binding capacity. To our knowledge, this is the first instance of the transformation of a viral protein of unknown function to a functional silencing suppressor.
\end{abstract}

$\mathrm{R}_{\mathrm{w}}^{\mathrm{s}}$ NA silencing is a sequence-specific cellular process that leads to RNA degradation, inhibition of translation of mRNAs, or heterochromatin formation (10). RNA silencing has several functions; one of the most important is to counteract viruses and transposons. Viruses evolved silencing suppressors to inhibit RNA silencing (1). Cellular proteins possessing WG/GW domains are known to bind Argonaute (AGO) via their tryptophan (W) residues $(3,4,6,13,15)$. The P1 protein of Sweet potato mild mottle virus (SPMMV) is a silencing suppressor that is able to counteract the active RNA-induced silencing complex (RISC) by binding AGO (5). Compared to the P1 proteins of members of the Potyvirus genus, ipomoviral SPMMV P1 has a long extension at its $\mathrm{N}$ terminal end harboring $3 \mathrm{WG} / \mathrm{GW}$ domains spanning amino acid (aa) 1 to aa 140 , and this region is absolutely necessary for suppressor activity and AGO binding (5). The closest homolog of SPMMV P1 is Sweet potato feathery mottle virus (SPFMV) P1 (14, 5). We sought to determine whether SPFMV P1 possesses RNA silencing suppressor activity. To do this, we prepared first-strand cDNA from RNA isolated from SPFMV-infected sweet potato plants commercially available at the German Collection of Microorganisms and Cell Cultures. Using degenerate primers (5'-AAG GATCCATGGCAWCYGYNATCBGYATYTGYGAA and 3'-AG AATTCTTTARWAYTGVDYGATRWATGGYARRRYRGAYCTA CCAAG) designed according to available sequence data, we amplified the P1 open reading frame of a Nigerian SPFMV isolate (GenBank accession number JQ742091). Sequence analysis revealed a 689 -aa protein that is 80 to $95 \%$ identical to known SPFMV P1 proteins. The N-terminal 193-aa region of SPFMV P1 was $41.5 \%$ identical to the corresponding part of SPMMV P1; the rest of the protein was $22 \%$ identical. However, the overall identity was $24.6 \%$. Although the N-terminal 193 -aa region of SPFMV P1 showed the highest homology to SPMMV P1, it contains only one WG/GW domain (Fig. 1A). To see if SPFMV P1 is able to inhibit RNA silencing, we performed the standard Agrobacterium coinfiltration assay (12). The coding region ending with a stop codon for SPFMV P1 was $\mathrm{N}$ terminally HA (hemagglutinin) tagged by being cloned into the binary vector pSanyi (7), transferred to agrobacteria, and then used with an agrobacterial strain harboring the ${ }^{35}$ S-labeled green fluorescent protein (GFP)-encoding reporter gene to coinfiltrate leaves of wild-type (WT) Nicotiana benthamiana. As a positive control, SPMMV P1 was used. Figure $1 \mathrm{~B}$ and $\mathrm{C}$ show that ${ }^{35} \mathrm{~S}$-GFP remained silenced in the presence of SPFMV P1; however, as was shown before, SPMMV P1 strongly inhibited silencing (5). Previously it was shown that the loss of any two of the WG/GW motifs of SPMMV P1 correlated with loss of silencing suppressor activity (5). We hypothesized, therefore, that the sole WG/GW motif in WT SPFMV P1 might be insufficient for silencing suppressor activity. Due to the high degree of amino acid identity between the SPFMV and SPMMV P1 proteins at their $\mathrm{N}$-terminal ends, we determined amino acids in SPFMV P1 corresponding to the tryptophan residues of the second and third WG/GW motifs in SPMMV P1 (Fig. 1A). Using primers GATGT CCTGGATGGATGGAAGTGTGACAGCTGC and GCAGCTGT CACACTTCCATCCATCCAGGACATC along with primers CTA GAGCGTTAGGAGGGTGGGATGCATACTGTG and CACAGT ATGCATCCCACCCTCCTAACGCTCTAG (nucleotide changes are underlined), the histidine residue at position 109 and the tyrosine residue at position 139 were changed to tryptophan using the QuikChange XL mutagenesis kit. Thus, three mutants, H109W, Y139W, and H109W/Y139W, were created, resulting in one additional WG/GW motif in the first two mutants, and two additional WG/GW motifs in the third. The mutants were tested for suppressor activity as described above. The H109W and Y139W mutants did not show silencing suppressor activity however, the H109W/Y139W mutant inhibited RNA silencing as well as SPMMV P1 (Fig. 1B). Our in vivo data were confirmed by Northern and Western blotting as described previously (5) (Fig. 1C).

The latter is a silencing suppressor that is able to inhibit active RISC (5). Next we checked if the highly homologous WT SPFMV P1 and/or any of the mutants we created interfere with active RISC. SPFMV strains expressing P1 and H109W, H139W, and H109W/Y139W mutant P1 were coinflitrated with the GFP1171.1 reporter gene into $N$. benthamiana as described previously (5). Our results revealed that neither WT P1, containing one WG/GW motif, nor H109W or H139W mutant P1, having two WG/GW motifs, demonstrated silencing suppressor activity. However, H109W/Y139W mutant P1, having three WG/GW mo-

Received 12 March 2012 Accepted 14 May 2012

Published ahead of print 23 May 2012

Address correspondence to Lóránt Lakatos, lakatos.lorant@med.u-szeged.hu

E.Z.S. and M.M. contributed equally to this work.

Copyright $\odot$ 2012, American Society for Microbiology. All Rights Reserved. doi:10.1128/JVI.00627-12 


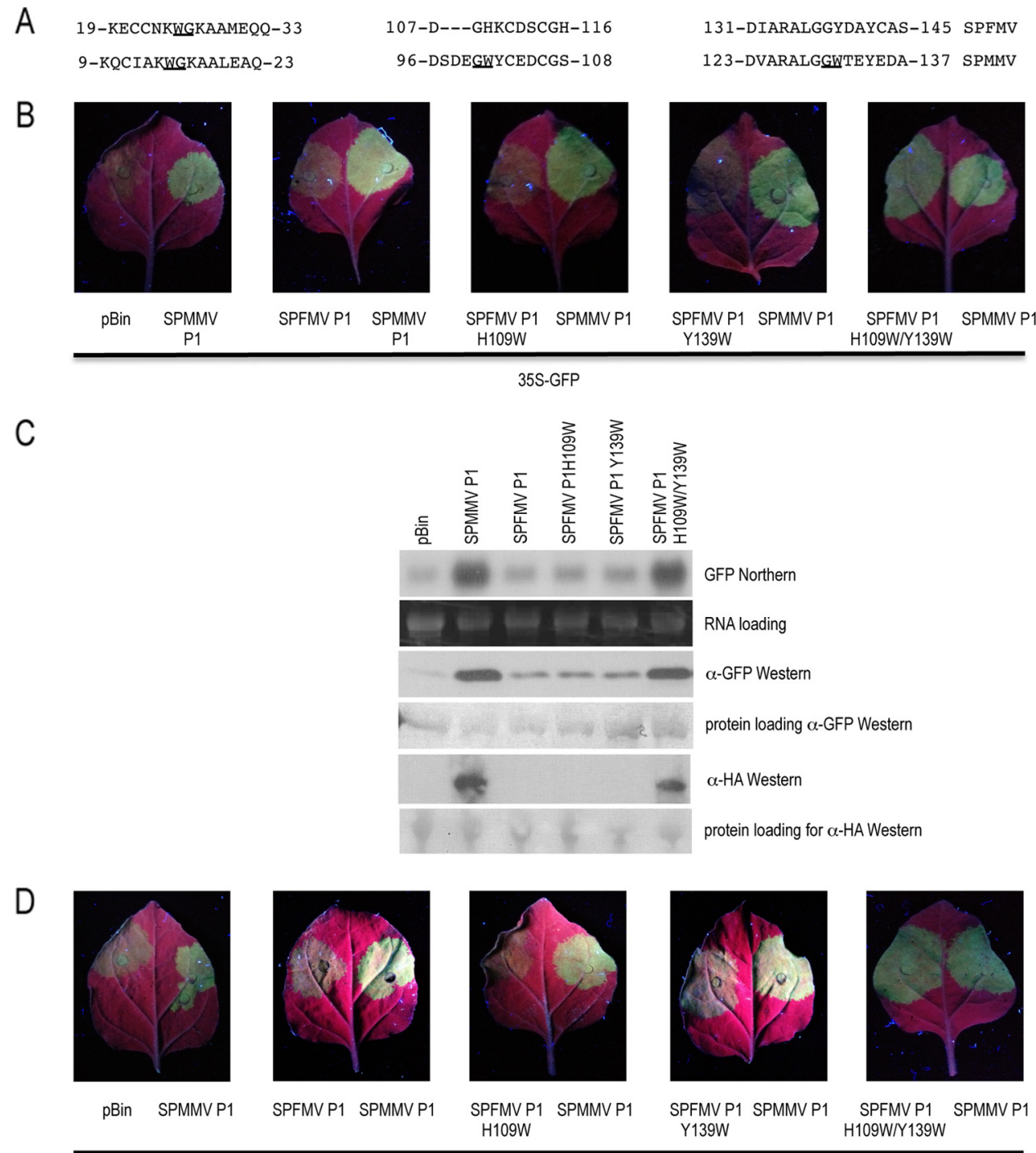

GFP-171.1

E

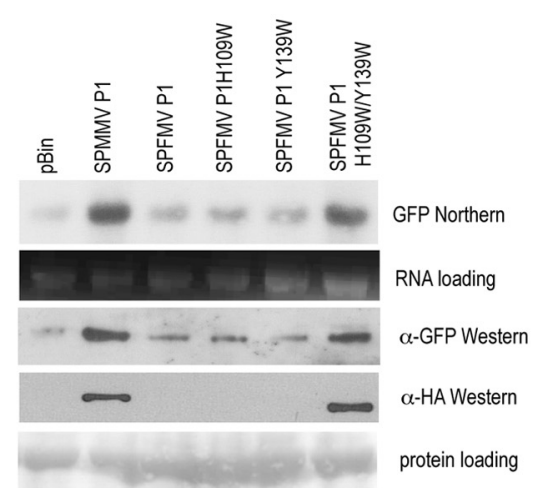

FIG 1 Analysis of SPFMV P1. (A) WG/GW motifs of SPFMV P1 and their corresponding SPMMV P1 parts. WG/GW amino acid duplets are underlined. Numbers indicate amino acid positions. In SPFMV P1, histidine 109 and tyrosine 139 are in bold. (B) Standard ${ }^{35}$ S-GFP agroinfiltration analysis of WT and mutant SPFMV P1 proteins. Infiltrated leaves at 3 days postinfection were illuminated with a hand-held UV lamp (Blak Ray B-100AP UV lamp; UVP), and pictures were taken with the camera of the iPhone 4S. (C) RNA and protein extracts of infiltrated patches were used to detect GFP expression by Northern and Western blotting. (D) Agroinfiltration analysis of WT and mutant SPFMV P1 proteins to inhibit active RISC. (E) Detection of GFP expression by Northern and Western blotting at 2 days postinfection. 


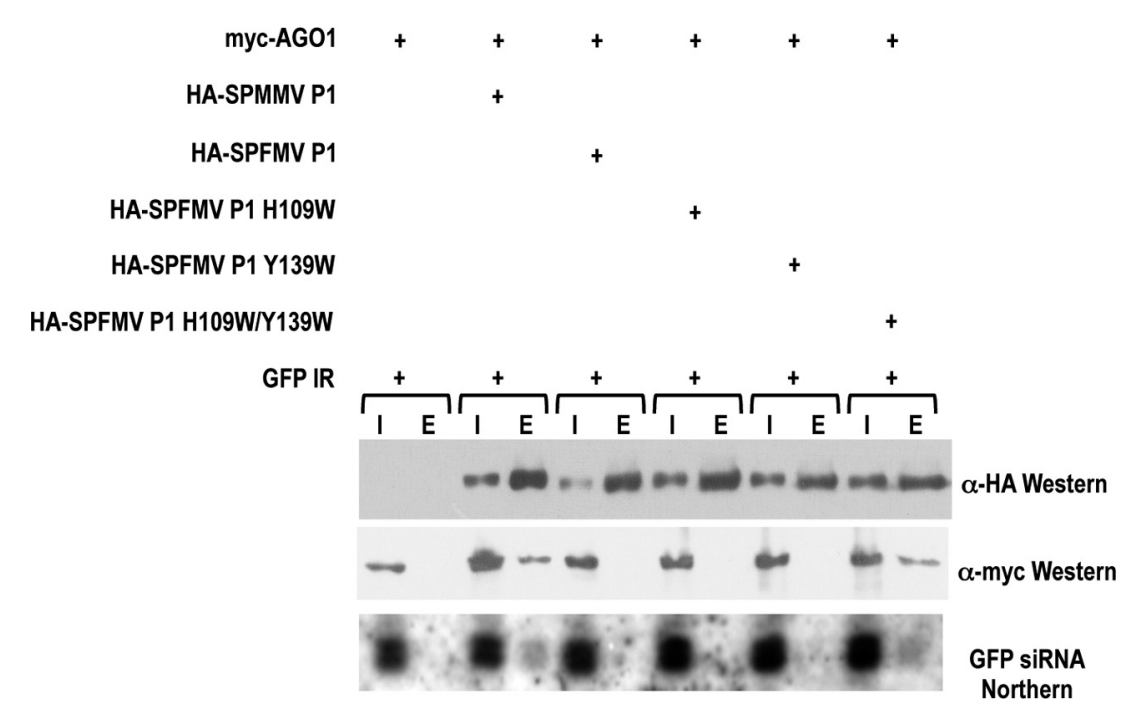

FIG 2 Physical interaction of AGO1 and WT and mutant SPFMV P1 proteins. Western and Northern analyses of inputs (I) and eluates (E) of immunoprecipitations carried out with extracts of infiltrated leaves. IR, inverted repeat.

tifs, showed a potent ability to inhibit active RISC (Fig. 1D). Northern and Western blotting detected high GFP and suppressor expression by H109W/Y139W mutant SPFMV P1, as well as by the positive control (Fig. 1E). However, the WT and mutant SPFMV P1 proteins, which did not show suppressor activity, could be detected only when they coinfiltrated plants with Tobacco etch virus HC-Pro (9) (data not shown).

To test AGO binding capacity, the HA-tagged WT and mutant forms of SPFMV P1 were used for coinfiltration with $6 \times$ mycAGO1 (16) and a ${ }^{35} \mathrm{~S}$-GFP inverted repeat. To avoid the effect of RNA silencing, the GFP16c/RDR6i N. benthamiana line was used in this experiment, which does not have silencing against (even transiently expressed) transgenes $(5,11)$. Western and Northern analyses of inputs and eluates of immunoprecipitations of the HA-tagged WT and mutant SPFMV and SPMMV P1 proteins were carried out. Small-RNA-loaded AGO binding ability was detected in the SPFMV H109W/ Y139W mutant and WT SPMMV P1 proteins but not in the SPFMV WT or H109W or Y139W mutant P1 protein (Fig. 2), thus indicating that silencing suppressor activity strongly correlated with the capability of AGO binding. Any of the two WG/GW motifs was sufficient for silencing of suppressor activity and AGO binding in the case of SPMMV P1 (5). However, three WG/GW motifs were absolutely required for SPFMV P1 to gain silencing suppressor activity.

Bioinformatic analysis showed a close evolutionary relationship between the P1 proteins of SPMMV and SPFMV (14). Although WT SPFMV P1 did not show any silencing suppressor activity, remodeling of the AGO hook by changing only two amino acids to tryptophan resulted in a protein that inhibits active RISC by the same mechanism as the SPMMV P1 prototype (5). Thus, the close evolutionary relationship between the P1 proteins of SPMMV and SPFMV was further proven by our functional analyses. SPFMV, in a synergistic interaction with Sweet potato chlorotic stunt virus (SPCSV), causes the very severe sweet potato virus disease (8). RNase 3 protein, the silencing suppressor of SPCSV, was found to mediate viral synergism between SPCSV and SPFMV (2). In such a synergistic interaction, one powerful suppressor can support the spread of two viruses and that might explain why SPFMV P1 did not bear silencing suppressor activity.

Finally, to our knowledge, this is the first instance in which a viral protein of unknown function was turned into a functional RNA silencing suppressor.

\section{ACKNOWLEDGMENTS}

This research was supported by a grant from the Hungarian Scientific Research Fund (OTKA K81591) and grants TÁMOP-4.2.1/B-09/1/ KONV.-2010-0005 and TÁMOP-4.2.2/B-10/1-2011-0012. Lóránt Lakatos was a recipient of the Bólyai János fellowship.

We are grateful to Andrew McDowell for critical reading of the manuscript.

\section{REFERENCES}

1. Burgyán J, Havelda Z. 2011. Viral suppressors of RNA silencing. Trends Plant Sci. 16:265-272.

2. Cuellar WJ, et al. 2009. Elimination of antiviral defense by viral RNase III. Proc. Natl. Acad. Sci. U. S. A. 106:10354-10358.

3. Dalmay T, Horsefield R, Braunstein TH, Baulcombe DC. 2001. SDE3 encodes an RNA helicase required for post-transcriptional gene silencing in Arabidopsis. EMBO J. 20:2069-2078.

4. El-Shami M, et al. 2007. Reiterated WG/GW motifs form functionally and evolutionarily conserved ARGONAUTE-binding platforms in RNAirelated components. Genes Dev. 21:2539-2544.

5. Giner A, Lakatos L, Garcia-Chapa M, Lopez-Moya JJ, Burgyán J. 2010. Viral protein inhibits RISC activity by argonaute binding through conserved WG/GW motifs. PLoS Pathog. 6:e1000996. doi:10.1371/ journal.ppat.1000996.

6. Herr AJ, Jensen MB, Dalmay T, Baulcombe DC. 2005. RNA polymerase IV directs silencing of endogenous DNA. Science 308:118-120.

7. Kertész S, et al. 2006. Both introns and long 3'-UTRs operate as cis-acting elements to trigger nonsense-mediated decay in plants. Nucleic Acids Res. 34:6147-6157.

8. Kreuze JF, et al. 2008. RNA silencing-mediated resistance to a crinivirus (Closteroviridae) in cultivated sweet potato (Ipomoea batatas L.) and development of sweet potato virus disease following co-infection with a potyvirus. Mol. Plant Pathol. 9:589-598.

9. Lakatos L, et al. 2006. Small RNA binding is a common strategy to suppress RNA silencing by several viral suppressors. EMBO J. 25:2768-2780.

10. Melnyk CW, Molnar A, Baulcombe DC. 2011. Intercellular and systemic movement of RNA silencing signals. EMBO J. 30:3553-3563.

11. Schwach F, Vaistij FE, Jones L, Baulcombe DC. 2005. An RNA- 
dependent RNA polymerase prevents meristem invasion by potato virus $\mathrm{X}$ and is required for the activity but not the production of a systemic silencing signal. Plant Physiol. 138:1842-1852.

12. Silhavy D, et al. 2002. A viral protein suppresses RNA silencing and binds silencing-generated, 21- to 25-nucleotide double-stranded RNAs. EMBO J. 21:3070-3080.

13. Till S, et al. 2007. A conserved motif in Argonaute-interacting proteins mediates functional interactions through the Argonaute PIWI domain. Nat. Struct. Mol. Biol. 14:897-903.
14. Valli A, Lopez-Moya JJ, Garcia JA. 2007. Recombination and gene duplication in the evolutionary diversification of P1 proteins in the family Potyviridae. J. Gen. Virol. 88:1016-1028.

15. Zhang L, et al. 2007. Systematic identification of C. elegans miRISC proteins, miRNAs, and mRNA targets by their interactions with GW182 proteins AIN-1 and AIN-2. Mol. Cell 28:598-613.

16. Zhang X, et al. 2006. Cucumber mosaic virus-encoded 2b suppressor inhibits Arabidopsis Argonautel cleavage activity to counter plant defense. Genes Dev. 20:3255-3268. 


\section{II.}




\title{
Deletion series in the P1 protein of the Sweet potato mild mottle virus identifies the shortest fully functional RNA silencing suppressor domain
}

\author{
Edit Zsuzsanna Szabó ${ }^{1}$, Lajos Kemény ${ }^{1,2}$, Lóránt Lakatos ${ }^{1,2 *}$ \\ 'Department of Dermatology and Allergology, Faculty of Medicine, University of Szeged, Szeged, Hungary, ${ }^{2}$ MTA-SZTE \\ Dermatological Research Group, Szeged, Hungary
}

\begin{abstract}
RNA silencing is a part of the plant innate immune system that could effectively cope with intruders, like viruses. However, viruses evolved proteins that can suppress RNA silencing thus supporting virus spreading in the host. To counteract RNA silencing, suppressor proteins attack different players of RNA silencing pathway. The P1 protein of the Sweet potato mild mottle virus binds and inactivates small RNA loaded RISC complexes. Using a deletion series in the P1 protein we aimed to identify the possible smallest working version of P1. Our results revealed that the minimal RNA silencing suppressor domain of P1 is as small as 210 amino acids in size.

Acta Biol Szeged 58(2): (2014)
\end{abstract}

\author{
KEY WORDS \\ RNA silencing \\ plant \\ Sweet potato mild mottle virus \\ RNA silencing suppressor
}

RNA silencing is a post-transcriptional gene regulation mechanism conserved in almost all eukaryotes and involved in many essential biological processes, from development, physiological activity to the regulation of abiotic and biotic stress responses by micro RNAs (miRNA), genome defense by 24 nucleotide (nt) long small interfering RNAs (siRNAs) and in particular antiviral defense by $21 \mathrm{nt}$ siRNAs. RNA silencing negatively regulates genes expression (Herr and Baulcombe 2004).

The trigger of RNA silencing can be pri-miRNAs for miRNAs or double stranded (ds) RNAs as replicative forms of plant viruses. Trigger RNAs are processed into si- and miRNAs by the RNAse III type enzymes Dicers, then small RNAs are loaded into the Argonaute (AGO) protein containing protein complexes called RNA induced silencing complex (RISC). This process is referred to as RISC assembly. In RISC, one strand of the small RNA is eliminated resulting in the single stranded (ss) small RNA containing RISC complex (active RISC). Active RISC complexes are able to hamper gene expression either by cleaving the target RNA or by inhibiting the translation of the target RNA (Hutvagner and Simard 2008). Thus, Argonaute (AGO) proteins play a key role in RNA silencing.

In the last few years, several AGO binding proteins were identified. Most of them contain GW/WG (Gly-Trp/Trp-Gly) domains, which mediate the interaction with AGO. This group of proteins was named GW/WG proteins after the founding member GW182 protein of human. GW182 in animals bind
AGO and mediate the interaction with the polyA binding proteins to repress the translation of the target RNA (Pfaff et al. 2013). In Schizosaccharomyces pombe, transcriptional silencing involves AGO and TAS3 that shows high similarity to animal GW182 proteins (Pfaff et al. 2013). In plants, heterochromatin silencing exploits a couple of GW/WG proteins, such as the second largest subunit of the RNA polymerase V complex and SPT5 protein (Bies-Etheve et al. 2009; Herr et al. 2005). Moreover, the GW/WG protein SUO was identified in Arabidopsis thaliana to be involved in miRNA driven RNA silencing (Yang et al. 2012). Thus, these GW/ WG proteins have a positive effect on RNA silencing and are absolutely required for the efficient carrying RNA silencing into execution.

Two viral proteins bearing WG/GW domains were found to have a negative effect on RNA silencing. The $\mathrm{p} 38$ protein of the Turnip crinkle virus (TCV) sequesters small RNA unloaded AGO1 (Azevedo et al. 2010). However, the P1 RNA silencing suppressor protein of the Sweet potato mild mottle virus (SPMMV) is markedly different from that of $\mathrm{p} 38$. SPMMV P1 binds AGO1 loaded with si- or miRNAs, thus inhibiting target cleavage of active RISC complexes. Mutational analysis revealed three WG/GW motifs, resembling the AGO binding platform conserved in plants and metazoans, at the $\mathrm{N}$-terminal part of $\mathrm{P} 1$, which are required for AGO binding and silencing suppressor activity (Giner et al. 2010).

Recently, we found that the first 383 amino acid (aa) region of the SPMMV P1 renders RNA silencing suppressor activity (Giner et al. 2010). Thus, our aim was to find the smallest region of the $\mathrm{P} 1$ protein bearing fully functional suppressor activity. Our results based on a series of truncation of 


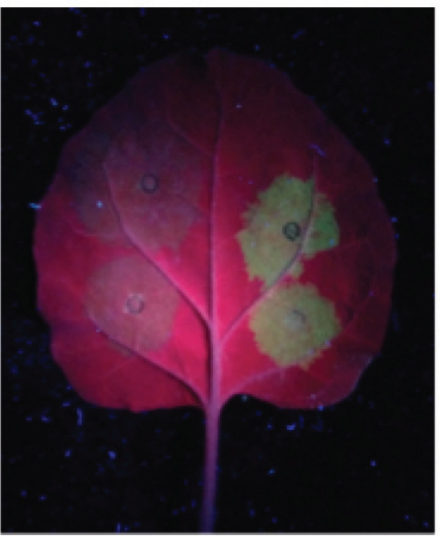

empty P1 1-383

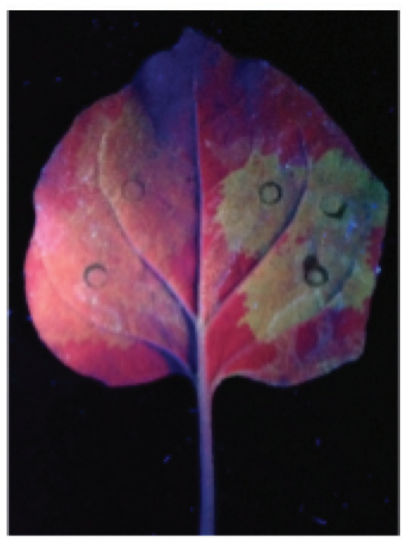

P1 1-120 P1 1-383

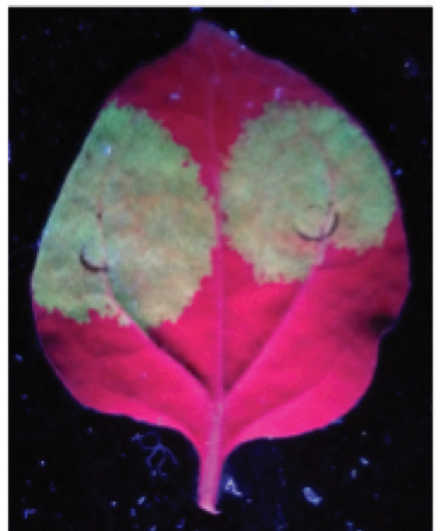

P1 1-210

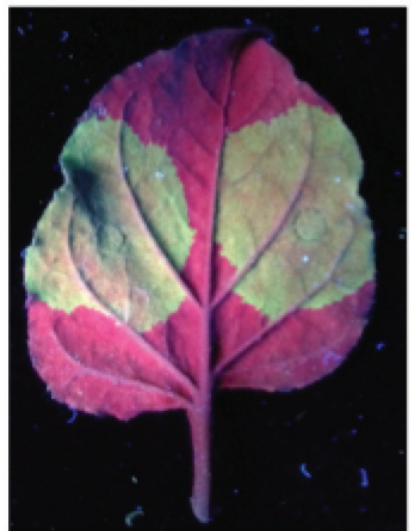

P1 1-360

P1 1-383

Figure 1. RNA silencing suppressor activity of the truncated mutants. The first panel shows empty vector infiltrated sample, used as negative control. The mutant of interest was infiltrated as shown in the second, third and fourth panel. On the right side of each panel $\mathrm{P} 1_{1-383}$ was infiltrated, as positive control.

the $\mathrm{P} 1$ protein from the C-terminal end showed that the 1-210, but not 1-120, amino acids region is fully functional.

\section{Materials and Methods}

\section{Plant materials}

Wild-type Nicotiana benthamiana plants grown in soil under normal growth conditions were used for, virus infection and agroinfiltration. Plants were grown in Phytotron (Versatile Environmental Test Chambers; Sanyo, Tokyo, Japan) under a 14-h light $(50 \mathrm{mE} \mathrm{m} \pm 2 \mathrm{~s} \pm 1)$ and 10 -h dark regime at $23{ }^{\circ} \mathrm{C}$.

\section{Agroinfiltration}

Agroinfiltration was essentially carried out as described earlier (Silhavy et al. 2002). Plasmid DNA was introduced into the Agrobacterium tumefaciens C58C1 strain by triparental mating (Wise et al. 2006). Agrobacterium strains harboring the expression plasmids were cultured at $28^{\circ} \mathrm{C}$ in $\mathrm{LB}$ medium in the presence of $5 \mu \mathrm{g} / \mathrm{ml}$ tetracycline and $100 \mu \mathrm{g} / \mathrm{ml} \mathrm{kana}-$ mycin. Cultures were centrifuged at room temperature with $1000 \mathrm{~g}$ to pellet the bacteria, then resuspended in the induction solution containing $10 \mathrm{mM}$ MES (pH 5.6), $10 \mathrm{mM} \mathrm{MgCl}_{2}$ and $150 \mu \mathrm{M}$ acetosyringone. Optical density of the cultures were determined and diluted to an $\mathrm{OD}_{600}$ of 0.3 for suppressor and 0.1 for reporter genes. Diluted and mixed Agrobacterium strains were incubated in the induction solution for 1-3 hours at room temperature before infiltration.

\section{Primers used in this study}

P1-5'-end: 5'GGGGATTCCCTAGAATGGGGAAATCCA AACTC 3'

P1 ${ }_{1-360}-3$ '-end: 5' TGAATTCTCATGCCACCGTGATGG-
GACACACCATAGC 3'

P1 $1_{1-305}$-3'-end: 5' TGAATTCTCATGTCTTTGTAACCCACATAACTGC 3'

P1 ${ }_{1-210}-3$ '-end: 5 ' TGAATTCTCAAATTGAGAAAACAGTTTCCTCAAAAACC 3'

P1 ${ }_{1-120}$-3' '-end: 5' TGAATTCTCAGTTATCAAGTACATTGTCGTCGCGCTTGTT 3'

\section{Western blot analysis}

To the blot analysis, samples were collected in $2 \mathrm{~cm}$ diameter. The samples were extracted in $2 \mathrm{x}$ sodium dodecyl sulfate (SDS) loading puffer and boiled for 5 minutes, after sample preparation $10 \%$ sodium dodecyl sulfate polyacrylamide gel electrophoresis (SDS-PAGE) was run. Blocking was carried out in 5\% dry milk in phosphate buffered saline (PBS) at every turn. Anti-HA (anti-influenza hemagglutinin, 1:3000 in $5 \%$ dry milk) and anti-GFP (anti-green fluorescent protein, 1:5000) was used for HA and GFP tagged samples, respectively. Anti rabbit HRP (anti-rabbit IgG conjugated to horseradish peroxidase, 1:5000) was used as secondary antibody. At the co-immunoprecipitation anti-Ha and anti-myc antibody was used (1:5000 in 2\% dry milk; secondary antibody was anti-rabbit HRP, 1:5000).

\section{Results and Discussion}

It was previously demonstrated that the $\mathrm{N}$-terminal 383 amino acid region of SPMMV P1 possessed the silencing suppressor domain (Giner et al. 2010). If the N-terminally HA-tagged full length SPMMV P1 was infiltrated into $N$. benthamiana plants and immunoprecipitated, the minority of the HA-tagged protein was proven full length (Lakatos, unpublished). This result might not be surprising, since it is already known that 

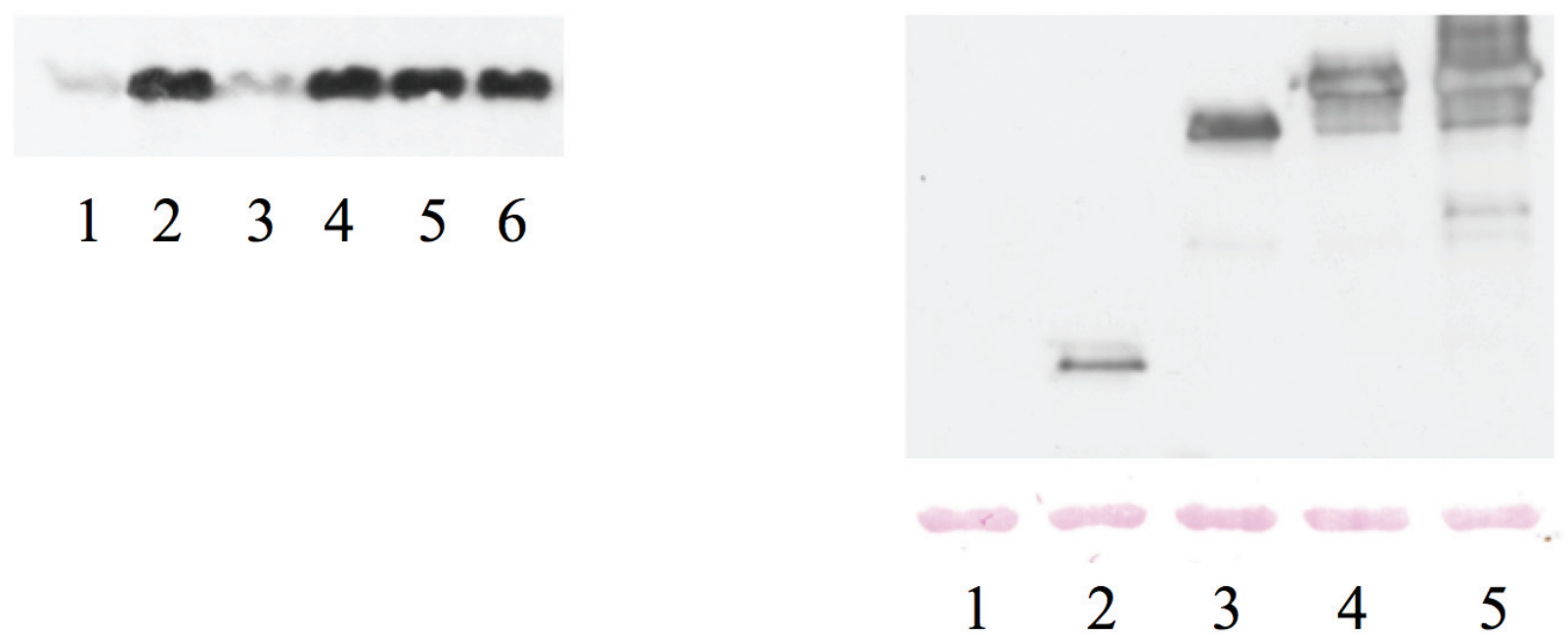

Figure 2. Expression analysis of GFP and the truncated suppressor mutants. Panel A, GFP detected by anti-GFP polyclonal antibody; lanes: 1 ,

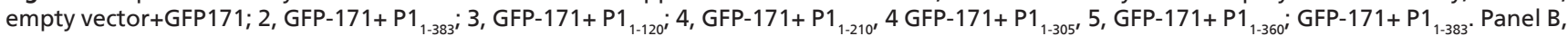

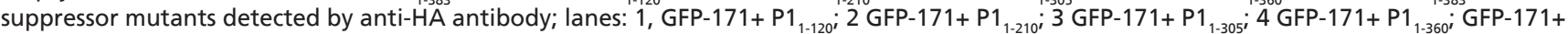
$\mathrm{P} 1_{1-383}$; lower panel represents the loading control.

maturation of the huge potyviral polypeptide translated occurs via the intrinsic protease activities of the polypeptide. Even $\mathrm{P} 1$ has a protease domain in its C-terminal, which is required for liberation of $\mathrm{P} 1$ from the primary translation product (Valli et al. 2007). Thus, the $\mathrm{C}$-terminal truncation of $\mathrm{P} 1$ can be a consequence of its own protease activity, but the action of the plant proteases could not be excluded.

Our aim was to find out, whether these shorter versions of P1 still have RNA silencing suppressor activity. To answer this question, we systematically performed C-terminal truncations on the SPMMV P1 protein. To this end, we amplified the P1 coding region with P1-5' -end primer (annealing to the translational start codon) and $\mathrm{P} 1_{1-360^{-}}, \mathrm{P} 1_{1-305^{-}}, \mathrm{P} 1_{1-210^{-}}$and $\mathrm{P} 1_{1-120}-3$ '-end primers resulting in 360-, 305-, 210 - and 120-aa versions of P1. PCR products were cloned into the TOPO II vector (Invitrogen) and sequenced from both sides. These inserts were cloned into pSanyi plant expression vector (Kertesz et al. 2006) to express them as fusion protein with a HA-tag at their N-terminal end. Agrobacterium strains harboring these constructs were coinfiltrated with reporter construct GFP171.1 (Parizotto et al. 2004) to check for silencing suppressor activity in $N$. benthamiana (Giner et al. 2010). SPMMV P1 ${ }_{383}$ was used as a control, because this truncated version was known to have silencing suppressor activity. Forty eight hours post-infiltration, visual inspection of the infiltrated leaves was carried out under UV light. We found that the SPMMV P1, ${ }_{383}, \mathrm{P} 1_{1-360}, \mathrm{P} 1_{1-305}$, and $\mathrm{P} 1_{1-210}$ infiltrated leaves showed bright green fluorescence under UV light, indicating RNA silencing suppressor activity. However, the $\mathrm{P} 1_{1-120}$ infiltrated leaves were rather red, which demonstrated lack of silencing suppressor activity (Fig. 1). Then, Western blotting was carried out to detect GFP protein in the infiltrated leaves. Consistently with our visual inspection, strong GFP expression was found in the protein extracts of $\mathrm{P} 1_{1-383}, \mathrm{P} 1_{1-360}, \mathrm{P} 1_{1-305}$, and $\mathrm{P} 1_{1-210}$ infiltrated leaves, while significantly less GFP was detected, when GFP-171 or GFP-171 and P1 $1_{1-120}$ were infiltrated (Fig. 2A). These experiments clearly revealed that silencing suppressor function was lost in the case of the $\mathrm{P} 1_{1-120}$ mutant. We showed earlier that SPMMV P1 contains three WG/GW motifs at positions 15, 101 and 131 (Giner et al. 2010). Although, we found that changing W131 to A (alanine) did not significantly affect the silencing suppressor function, but in the case of the $\mathrm{P} 1_{1-120}$ mutant, excluding W131 and ten more amino acids might be detrimental for silencing suppressor activity (Giner et al. 2010). Finally, the expression of the N-terminally HAtagged truncated silencing suppressor proteins were examined by western blotting. Our results showed that extracts of leaves infiltrated with $\mathrm{P} 1_{1-210}, \mathrm{P}_{1-305}, \mathrm{P} 1_{1-360}$, and $\mathrm{P} 1_{1-383}$ showed high suppressor expression in increasing protein size (Fig 2B). On the other hand, leaves infiltrated with $\mathrm{P} 1_{1-120}$ did not express the corresponding protein. Of note, that extracts used in this experiment contained nearly the same amount of protein, as shown in the protein loading panel (Figure 2B). However, the SPMMV P1 $1_{1-120}$ protein, which did not show suppressor activity, could be detected only when they coinfiltrated in plants with Tobacco etch virus HC-Pro (data not shown) (Azevedo et al. 2010; Szabo et al. 2012). 
The prototype RNA silencing suppressor inhibiting preassembled RISC is the SPMMV P1 protein, which consists of 759 amino acids. As it was shown before, this large protein in size contains the RNA silencing suppressor domain at the $\mathrm{N}$-terminal part (Giner et al. 2010) and a protease domain conserved in the Potivirideae family (Valli et al. 2007). Shorter versions of P1 were found in unrelated experiments implicated the functionality of these proteins. Thus, we narrowed the silencing suppressor domain to the $\mathrm{N}$-terminal 210 amino acids of SPMMV P1. This truncated protein has full silencing suppressor activity, compared to longer versions.

\section{Acknowledgments}

This study was supported by the Hungarian Research Fund (OTKA) grants (NN107787 and NN11024) to LL. KL was funded by the European Union and co-financed by the European Social Fund (TÁMOP-4.2.2.A-11/1/KONV-2012-0035 and TÁMOP 4.2.4.A-2013/2-A2-SZJÖ-TOK-13.

\section{References}

Azevedo J, Garcia D, Pontier D, Ohnesorge S, Yu A, Garcia S, Braun L, Bergdoll M, Hakimi MA, Lagrange T, Voinnet O (2010) Argonaute quenching and global changes in Dicer homeostasis caused by a pathogen-encoded GW repeat protein. Genes Dev 24:904-915.

Bies-Etheve N, Pontier D, Lahmy S, Picart C, Vega D, Cooke R, and Lagrange T (2009) RNA-directed DNA methylation requires an AGO4interacting member of the SPT5 elongation factor family. EMBO Rep 10:649-654.

Giner A, Lakatos L, Garcia-Chapa M, Lopez-Moya JJ, Burgyan J (2010)
Viral protein inhibits RISC activity by argonaute binding through conserved WG/GW motifs. PLoS Pat 6:e1000996.

Herr AJ, Baulcombe DC (2004) RNA silencing pathways in plants. Cold Spring Harbor Symposia on Quantitative Biology 69:363-370.

Herr AJ, Jensen MB, Dalmay T, Baulcombe DC (2005) RNA polymerase IV directs silencing of endogenous DNA. Science 308:118-120.

Hutvagner G, Simard MJ (2008) Argonaute proteins: key players in RNA silencing. Nature reviews. Mol Cell Biol 9:22-32.

Kertesz S, Kerenyi Z, Merai Z, Bartos I, Palfy T, Barta E, Silhavy D (2006) Both introns and long 3'-UTRs operate as cis-acting elements to trigger nonsense-mediated decay in plants. Nucleic Acids Res 34:6147-6157.

Parizotto EA, Dunoyer P, Rahm N, Himber C, Voinnet O (2004) In vivo investigation of the transcription, processing, endonucleolytic activity, and functional relevance of the spatial distribution of a plant miRNA. Genes Dev 18:2237-2242.

Pfaff J, Hennig J, Herzog F, Aebersold R, Sattler M, Niessing D, Meister G (2013) Structural features of Argonaute-GW182 protein interactions. Proc Nat Acad Sci U S A 110:E3770-3779.

Silhavy D, Molnar A, Lucioli A, Szittya G, Hornyik C, Tavazza M, Burgyan J (2002) A viral protein suppresses RNA silencing and binds silencinggenerated, 21- to 25-nucleotide double-stranded RNAs. EMBO J 21:3070-3080.

Szabo EZ, Manczinger M, Goblos A, Kemeny L, Lakatos L (2012) Switching on RNA silencing suppressor activity by restoring argonaute binding to a viral protein. J Virol 86:8324-8327.

Valli A, Lopez-Moya JJ, Garcia JA (2007). Recombination and gene duplication in the evolutionary diversification of $\mathrm{P} 1$ proteins in the family Potyviridae. J Gen Virol 88:1016-1028.

Wise AA, Liu Z, Binns AN (2006) Three methods for the introduction of foreign DNA into Agrobacterium. Methods in molecular biology 343:43-53.

Yang L, Wu G, Poethig RS (2012) Mutations in the GW-repeat protein SUO reveal a developmental function for microRNA-mediated translational repression in Arabidopsis. Proceedings of the National Academy of Sciences of the United States of America 109:315-320. 